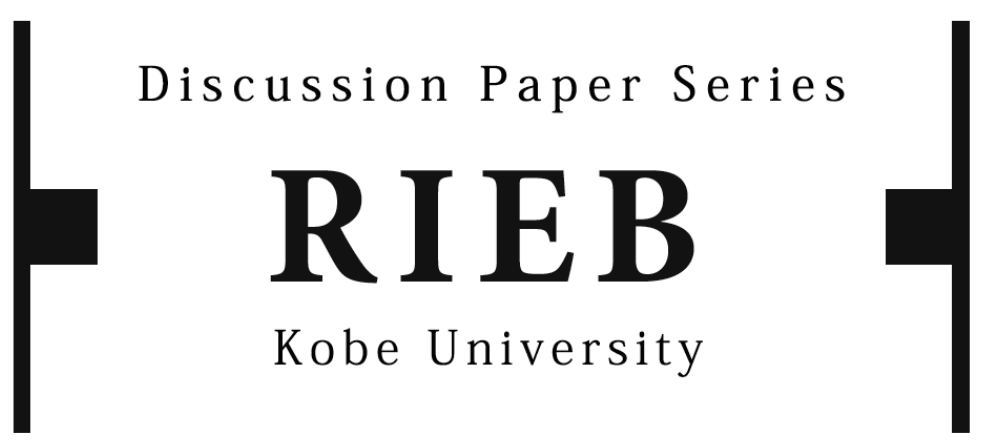

DP2015-20

Declining Nutrient Intake in a Growing China: Does Household Heterogeneity Matter?*

\author{
Jing YOU \\ Katsushi S. IMAI \\ Raghav GAIHA
}

May 19, 2015

* The Discussion Papers are a series of research papers in their draft form, circulated to encourage discussion and comment. Citation and use of such a paper should take account of its provisional character. In some cases, a written consent of the author may be required.

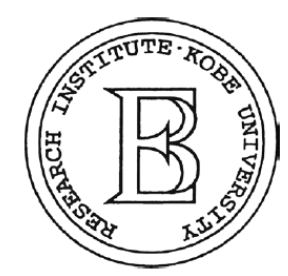

Research Institute for Economics and Business Administration Kobe University 


\title{
Declining nutrient intake in a growing China: Does household heterogeneity matter?
}

\author{
Jing You, ${ }^{1}$ Katsushi S. Imai, ${ }^{2}$ and Raghav Gaiha ${ }^{3}$ \\ 1. School of Agricultural Economics and Rural Development, Renmin University of China \\ 2. Economics, School of Social Sciences, University of Manchester \& RIEB, Kobe \\ University
}

3. Faculty of Management Studies, University of Delhi, India \& Department of Global Health and Population, Harvard School of Public Health, Harvard University, Boston, USA

This Draft: 2 September 2015

\begin{abstract}
This paper uses Chinese household data for 1989-2009 to explain why mean nutrient intake has declined despite economic growth. We focus on household heterogeneity in nutrient intake response to increases in household income allowing for its endogeneity. A quantile instrumental-variable fixed-effects panel estimation shows that rising income tends to reduce inequality in macronutrient intake in both urban and rural areas in 20042009. This is driven by increases in nutrient intake for the urban nutrient poor and falls in nutrient intake for the rural nutrient non-poor. On the other hand, fluctuations in prices of meat, eggs and oil increase nutrition poverty.
\end{abstract}

Key words: nutrition, nutrient intake, inequality, poverty, obesity, IV regression, quantile regression, China

JEL classification: C23, I10, I31, O53, Q18

* Corresponding author:

Jing You (Dr)

Address: School of Agricultural Economics and Rural Development, Renmin University of China, 59 Zhongguancun Street, Beijing 100872, China

E-mail: jing.you@ ruc.edu.cn

Tel.: +86-(0)10-6251-1061; Fax: +86-(0)10-6251-1064

\section{Acknowledgements:}

This research is funded by the National Natural Science Foundation of China (NSFC) (Grant No.: 71403282), the Humanity and Social Science Foundation of the Ministry of Education of China (Grant No.: 13YJCZH231), and the Research Project Grant of the School of Agricultural Economics and Rural Development at Renmin University of China. Additional financial support from the University of Manchester (the Faculty SIRF grant) is also greatly appreciated. We are grateful to Thomas Elhaut for his support and guidance throughout this study and for his insistence on highest standards of analytical rigour. We are grateful to Derek Headey, David Bloom, and an anonymous referee at BWPI for valuable comments. We also appreciate valuable comments from the editor and three anonymous of the journal. The views expressed are personal and not necessarily of the organisations to which we are affiliated or of IFAD. 


\section{Declining nutrient intake in a growing China: Does household heterogeneity matter?}

\section{Introduction}

Chinese households have experienced continuous income growth for more than three decades. Per capita disposable income increased at an annual rate of 3.4\% from 1980 to 2012 for urban households, and $2.8 \%$ from 1985 to 2012 for rural households. ${ }^{1}$ High income growth helped the income poverty headcount ratio (based on the US $\$ 1.25$ poverty line) plummet from $85.3 \%$ in 1981 to $11.8 \%$ in $2009 .{ }^{2}$ Despite economic growth and reduction in income poverty, the household calorie intake declined in 2000-2004 (You et al., 2014). ${ }^{3}$ Based on the nationally representative China Health and Nutrition Survey (CHNS) in 2000-2006, Shimokawa (2010) finds little correlation between household wealth and nutrient intake. In both urban and rural areas, the income elasticities of food (e.g., grain and vegetables) and nutrients (e.g., calories and protein) are nearly zero in the range of low household income (Gale and Huang, 2007; Bishop et al., 2010) and even negative as income keeps rising (Huang and Gale, 2009), implying a satiation for food consumption for wealthy households (Zheng and Henneberry, 2010). Ma et al. (2004) and Hovhannisyan and Gould (2011) also find that expenditure elasticities became smaller and stabilised over the period 1995-2003.

As a result, low calorie or nutrient intake and dramatic income poverty reduction have co-existed in China's economic development. This is in sharp contrast to conventional wisdom and cross-country studies documenting positive impacts of income growth on nutrition (e.g. Headey, 2013). However, FAO (2013) argues that in countries where food

\footnotetext{
${ }^{1}$ The authors' calculations based on the data from China Statistical Yearbook (published by National Bureau of Statistics of China).

${ }^{2}$ Based on Chen and Ravallion (2010) and World Bank (2014).

${ }^{3}$ However, malnutrition has been alleviated, especially for children. For instance, the prevalence of stunting of children under 5 dropped from $33.1 \%$ in 1990 to $13 \%$ in 2009 using the government's national survey data (Chen, 2014). Our study, while supplemented by the analysis of undernourishment and obesity, mainly focuses on household nutrient intake because we use it as an important proxy for food security to see how it has changed over time in response to increases in income at various nutrient intake levels.
} 
insecurity is more pervasive, nutrition is weakly associated with income. Ample food availability and the shifts in consumption and lifestyle benefiting from income increases do not necessarily enable improvement in nutrition in terms of calorie intake, e.g., in India in 2004-2009 (Gaiha et al., 2014a). Why has not rapid and substantial income growth translated into higher nutrient intake? This is a central question that the present study seeks to address by examining the link between household income and nutrient intake. In particular, heterogeneity in household response to income increases and other factors will be taken into consideration. Supplementary analysis will be carried out for undernourishment and obesity.

One explanation for the lower nutrient intake despite higher economic growth pertains to the dietary transition of Chinese households in recent years. Household per capita consumption of fat and oil grew annually at an average of $2.7 \%$ in rural areas and $11.6 \%$ in urban areas between 2003 and 2011 (You, 2014), while lower amounts of vegetables and fruits were consumed over time. Fine grains and rice became increasingly more popular than coarse grains (Carter and Zhong, 1999). Chinese diet has been shifting away from traditional foods with coarse grains as the staple to the westernised high-fat animal-oriented and/or processed foods (Du et al., 2004). The CHNS data suggest that income effects on low-fat and high-fibre food, such as wheat-flour products and coarse grains, fell from 1989 to 1993 , relatively more among richer households, while income elasticities of pork, edible oil and eggs increased significantly (Guo et al., 2000). Despite a number of studies documenting preferences towards a western-diet, their micro-level datasets cover either urban or rural areas, and the time period is too short to capture long and gradual socio-economic transitions. More importantly, there has not been any direct analysis of whether the above changes in Chinese diet are associated with the decline in nutrient intake. It is important in this context to investigate the relative importance of dietary transitions to declining nutrient intake, compared to other possible contributing factors, for example, less energy demand in 
production activities and daily life as a natural consequence of socioeconomic development as well as the rise and fluctuations in food prices. ${ }^{4}$

Another explanation for the relation between low nutrient intake and high income growth is given by our focus on uncertainty households would face in making livelihood decisions. Meng et al. (2009) find that income elasticities of caloric intake are not close to zero based on the 1986-2000 waves of the Urban Household Survey conducted annually by the National Bureau of Statistics (NBS) in all provinces. They found that the poorer the individuals were, the higher the income elasticities of calorie consumption became. It is the soaring food prices in the early 1990s and income uncertainty - proxied by the proportion of household labour force working in the state sector and the household savings rate - that supressed calorie consumption, especially for those at the lower end of the income distribution. In fact, income and consumption uncertainty has risen markedly not only in urban (Chamon et al., 2013) but also in rural China (Whalley and Yue, 2009), causing various negative impacts on household livelihood. To the best of our knowledge, Meng et al. (2009) is the only study which has estimated the nutritional effects of income uncertainties during major social reforms. However, their measure of uncertainty only reflects the job instability and the heavy burden of education, medical and housing expenses only in urban areas.

This paper aims to examine the association between household income and nutrient intake during the period of China's remarkable economic development. It considers households' heterogeneity in terms of their adjustment of nutrient intake in response to the increase in household income. We aim to provide the first comprehensive set of results on the determinants of intake of macronutrients in both urban and rural China based on the nationwide household panel surveys for two decades (1989-2009). This is sought to be achieved by

\footnotetext{
${ }^{4}$ A similar income-nutrition puzzle has also been observed in rural India (e.g. Deaton and Dreze, 2009).
} 
taking into account not only household income, but also lifestyle changes, dietary preferences and uncertainty households tend to face in making livelihood decisions in a context of volatile food prices and unanticipated surges. Furthermore, an important point of departure of the present study from the extant literature is to model (i) various determinants of nutrient intake conditional on the household's position in distribution of nutrient intake, i.e. households' heterogeneity in their nutrient intake response to income changes, and (ii) the endogeneity of household income and its components in estimating these distributional effects. Our model seeks to provide consistent estimates of the effect of income on nutrient intake conditional on different levels of nutrient intake. The same model is applied to undernourishment and obesity in a supplementary analysis. We expect to obtain insights into China's experience of both rising income and declining nutrient intakes in recent years. The analysis could thus inform government policies aiming at nutritional improvement and food security not only for China, but also for other developing countries.

The remainder of this paper is organised as follows. The next section summarises our data. Section 3 spells out the estimation strategy. Section 4 discusses econometric results and the final section provides concluding observations and policy implications.

\section{Data}

We use the China Health and Nutrition Survey (CHNS) conducted by the Carolina Population Center at the University of North Carolina in 1989, 1991, 1993, 1997, 2000, 2004, 2006 and 2009. The multi-stage random sampling method and broadly same questionnaires have been applied to each wave. ${ }^{5}$ The sample provinces are spread across northeast (Liaoning and Heilongjiang), coastal (Jiangsu and Shandong), central (Henan, Hubei and Hunan), and southwest regions (Guangxi and Guizhou). There are about 4,400 households including

\footnotetext{
5 Detailed information on sampling procedures can be found on the CHNS webpage: http://www.cpc.unc.edu/projects/china [accessed on 2 May, 2014].
} 
26,000 individuals in each wave, with a higher proportion for rural than urban households defined by their actual places of residence. We have chosen household as the main unit of the analysis and have constructed pooled cross-sectional data as well as the (unbalanced) panel dataset based on 8 rounds of CHNS for our empirical analyses. After excluding households with missing values on key nutrition and economic indicators, we extract 29,402 households in the pooled data. The sample size for each round varies from 2,174 in 1989 to 4,444 in 2009 . The share of urban households ranges between 29.8\% (in 2000) and 39.7\% (in 1989). As scrutinised by Zhang et al. (2014), the sampling in the CHNS assures its provincial representativeness and the data are particularly useful for research on health and nutrition as the data on food consumption and nutrition were collected by using a diary approach considered more precise than a retrospective-survey approach in other studies. However, in 1989, the dietary data were only obtained for children younger than 6 years and adults aged 20-45 years within sample households due to constraints of funding (Popkin et al., 2010). This might have biased upwards the household adult equivalent nutrient intake in the first wave.

While our statistical analyses were based on the full sample (8 waves), the main econometric estimations were carried out by using subsample covering 3 waves in 2004, 2006 and 2009 because some crucial variables (e.g. food knowledge, cultural/preference indicators) have only been collected since 2004. The number of observations has been kept to the minimum common set of all explanatory variables. The final sample sizes are 2,368 for urban areas and 3,919 for urban areas. We have also carried out estimations for 8 waves using only selected explanatory variables for 7,831 urban households and 18,416 rural households.

Households' consumption of various food items (in quantity) was recorded in a 24-hour recall diary on 3 consecutive days which were randomly chosen within a week. The initial amount of each food item (including both self-produced and purchased items) and the amount 
of remaining and discarded food items as well as those purchased and eaten outside home during the 3-day recording period were all scaled and recorded at the individual level. As such, food consumption per person per day is highly precise. According to the 1989, 1991 and 1992 Food Composition Tables issued by the Institute of Nutrition and Food Hygiene at the Chinese Academy of Preventative Medicine, the CHNS team translated the quantity of each food item into the individuals' 3-day average total energy intake (in kcal) and different macronutrients such as fat, carbohydrates and protein (in grams). We use these converted individual nutrition data to further calculate our variables of interest. Definitions and descriptive statistics of all variables are found in Appendix 1.

Our data suggest that the household per capita equivalent net income had quadrupled over the period 1989-2009. ${ }^{6}$ By contrast, Figure 1 illustrates a decreasing trend of household total nutrient intake. ${ }^{7}$ The household per adult equivalent total nutrient intake per day decreased from $3,629 \mathrm{kcal}$ in 1989 to $2,883 \mathrm{kcal}$ in $2009 .{ }^{8}$ Figure 1 also shows that this decline was mainly driven by reduction in carbohydrate intake - its proportion in household nutrition consumption declined from $64 \%$ to $54 \%$. The proportion of fat in total nutrient intake increased from $24.5 \%$ in 1989 to $32.8 \%$ in 2009 (with a gradual increase in daily fat consumption), reaching the level higher than the threshold of $30 \%$ for a healthy diet according to the World Health Organisation (WHO). The proportion of protein also showed a marginal increase, from $11.0 \%$ to $12.1 \%$ during the same period, but the quantity of protein intake decreased from $100 \mathrm{~g}$ to $87 \mathrm{~g}$ per equivalent adult per day, still above the WHO's

\footnotetext{
${ }^{6}$ The household equivalence is defined by using the OECD criteria. See Appendix 1 for detailed definitions.

${ }^{7}$ The total nutrient intake is proxied by the sum of macronutrients, namely, fat, carbohydrate and protein. The FAO conversion rates are adopted to calculate total energy measured in kilocalorie from macronutrients measured in grams. See Appendix 1 for the detailed definition.

${ }^{8}$ These figures are higher than the FAO's estimates because we used the household equivalence to average total calories intake. The household per capita intake figures reduce to 2,770.69 in 1989 and 2,144.6 in 2009 if the household size (i.e., the total number of household members) is used as the denominator without taking into account the household's demographic structure. It should also be noted that high average calorie intake may be unrelated to the distribution of calorie intake.
} 
threshold of $66 \mathrm{~g}$. These statistics suggest that the diet pattern of Chinese households during the last two decades is consistent with recent studies we reviewed in Section 1.

\section{[Figure 1 to be inserted]}

\section{Methodology}

The analysis is at the disaggregated level for households' intake of different macronutrients. Let household $i$ consume nutrient $j$ with $j \in\{1,2,3\}$ at $t$. At the household level for each nutrient $j$, we regress the logarithmic household equivalent intake of the $j^{\text {th }}$ nutrient $\left(K_{i j t}\right)$ on a number of correlates of nutrition and health. Theoretically, this specification is related to the model of health production function (Thomas, 1994) where health or nutritional outcomes as an output is a function of a number of inputs (e.g. the quantity and quality of health care and individual and household characteristics) with a standard utility function of household members under a budget constraint for the household.

$$
\ln K_{i j t}=\beta_{0}+\boldsymbol{\beta}_{1} \mathbf{X}_{i t}+\boldsymbol{\beta}_{2} \mathbf{X}_{p t}+\boldsymbol{\beta}_{3} \mathbf{X}_{c t}+\boldsymbol{\beta}_{4} \mathbf{X}_{m t}+\sum_{s} \beta_{s} D_{s}+\sum_{t} \beta_{t} W_{t}+\alpha_{i j}+\varepsilon_{i j t}
$$

where the disturbances $\varepsilon_{i j t}$ follow an i.i.d. normal distribution for each nutrient $j$; the household fixed effect, $\alpha_{i j}$ denotes time-invariant and household-specific unobservables determining $i$ 's intake of nutrient $j$. The nutrient $\left(\ln K_{i j t}\right)$ we estimate is either fat, carbohydrate, protein, or the total calorie intake proxied by the sum of the three macronutrients using FAO's (2003) conversion rates. ${ }^{9}$ We include several important determinants of household nutrient intake or nutrient in equation (1). First, we use $\mathbf{X}_{i t}$, a vector of determinants of the nutrient in question, including the household per capita equivalent net income, the variable of our main interest. It also contains control variables,

\footnotetext{
${ }^{9}$ As an extension, a dependent variable is replaced by a binary variable on whether a household has any obese (or undernourished) member (Section 4.4).
} 
such as, demographic transition, education, gender, ethnicity, household wealth indicators (e.g. water quality, the toilet type and the main cooking fuels), labour supply, the household's average intensity of occupation-based physical activity intensity ${ }^{10}$, and health status. As shown in Figure 2, the household's average physical activity intensity decreased by $21 \%$ (from 3.17 in 1989 to 2.51 in 2009), and proportionally more for rural (36\%) than for urban (13\%) households. These are all expected given huge socioeconomic transitions in China, especially technological improvement and mechanisation of agricultural production in rural areas.

\section{[Figure 2 to be inserted]}

To capture the demographic transition, we specify five age groups in a 10-year interval and the proportion of adults within a household in each age cohort to account for demographic transition and household composition, respectively. They are posited to capture calorie and nutrient demand. This is particularly important for East Asia where the demographic bulge is moving from the young toward the older end of the working-age years (Bloom, 2011; Bloom et al., 2015). Together with the economic miracle and wide-ranging economic and social reforms, the demographic transition would have profound influences on nutrition demand, especially when there is a sharp age divide in food preference or taste for varieties.

Second, equation (1) includes $\mathbf{X}_{p t}$, the level and volatility of price indices of various foods to capture the increasing costs as well as uncertainties households tend to face in making livelihood decisions. The food categories include cereals, oil and fat, meat, eggs and vegetables. Comparison of the magnitudes of estimated coefficients $\left(\hat{\boldsymbol{\beta}}_{2}\right)$ across different food items also indicates their relative importance in affecting household nutrient intake.

\footnotetext{
${ }^{10}$ This is the categorical indicator ranging from 1 to 5 to measure the intensity of physical activities for household members. See Appendix 1 for details.
} 
Third, using the vector $\mathbf{X}_{c t}$ we control for households' knowledge of Chinese balanced diet as well as eating and living patterns. Fourth, $\mathbf{X}_{m t}$ captures community-level characteristics listed in Appendix 1. The provincial and wave dummies are denoted by $D_{s}$ and $W_{t}$, respectively, and also included in the equation.

We estimate equation (1) using unbalanced panel data with household fixed effects for urban and rural areas separately. In this model, there is likely to be endogeneity due to a twoway causality between income and nutrient intake. We use the standard instrumental variable estimation (IV) with two instruments: the proportion of farmland that suffered various natural disasters within the province, and the 5-year average provincial annual growth rate of average wage (per worker). Natural events are believed to be strictly exogenous and have been widely used as instruments for rural households' wellbeing. In this study, the proportion of farmland that has suffered from natural disasters is used as a proxy for proneness to natural disasters. Natural disasters are likely to have a negative impact on household income, but their effect on nutrition is weak or unlikely given relief through food aid (Bui et al., 2014; Noy, 2009). Our choice of the second instrument is guided by a strong link between provincial growth rate of wage and personal wages or income. While efficiency wage hypothesis predicts a strong link between wages and health or nutrition at individual levels (e.g. Bliss and Stern, 1978; Dasgupta, 1997; Jha et al., 2009), the provincial growth rate of wage is likely to be uncorrelated with personal decisions on nutrition consumption. ${ }^{11}$ To take into account further the simultaneous determination of wage and nutrient intake, we calculated the growth rate of provincial mean wage as the average over the past 5 years. These instruments are statistically valid (see Section 4.1).

\footnotetext{
${ }^{11}$ It is assumed here that the past provincial growth rate in wages is correlated with the current level of provincial wages through accumulation and then with the individual wage/income, where the effect is likely to be more or less direct. The instrument can affect the nutrient intake indirectly, but it should not have a direct effect on it. Changes in provincial wage can affect food price changes, through the increased demand for food or higher labour costs in the food/retail industry, but these effects are considered to be more indirect. This instrument is also statistically valid.
} 
To reflect heterogeneous outcomes on household nutrient within urban and rural areas, as discussed in Section 2, we combine Canay (2011) and Lee's (2007) approaches to estimate equation (1) for urban and rural areas separately, by using a quantile regression with household fixed effects and endogenous income. Specifically, equation (1) is re-written as the following two joint equations:

$$
\begin{gathered}
Q_{\ln K_{i j t} \mid \mathbf{X}, \mathbf{Z}}\left(\tau \mid \mathbf{X}, \ln y_{i t}\right)=\beta_{0}(\tau)+\beta_{1}(\tau) \ln y_{i t}+\mathbf{X} \boldsymbol{\beta}_{2}(\tau)+u_{i t} \\
Q_{\ln y_{i t} \mid \mathbf{X}, \mathbf{Z}}(\lambda \mid \mathbf{X}, \mathbf{Z})=\pi_{0}(\lambda)+\mathbf{X} \boldsymbol{\pi}_{1}(\lambda)+\mathbf{Z} \boldsymbol{\pi}_{2}(\lambda)+v_{i t}
\end{gathered}
$$

where $\tau$ and $\lambda$ denote the quantiles of household per capita equivalent nutrient intake and net income, respectively. In $y_{i t}$ denotes household $i$ 's natural logarithm of per capita equivalent net income at $t$. The vector $\mathbf{X}$ includes all correlates in equation (1), except income and household fixed effects. $\mathbf{Z}$ contains two instruments as stated before. The disturbances follow $\mathbf{U} \mid \mathbf{X}, \mathbf{Z} \sim U(0,1)$ and $\mathbf{V} \mid \mathbf{X}, \mathbf{Z} \sim U(0,1)$ where $\mathbf{U}$, containing household unobservable characteristics influencing nutrient intake, is correlated with $\mathbf{V}$, including unobservables that would determine the income level (e.g., capability for income generation), whereas income $\left(\ln y_{i t}\right)$ is uncorrelated with $\mathbf{V}$ but correlated with $\mathbf{U}$.

In the first step, we estimate equation (1) by a household fixed-effect panel specification to obtain standard within estimators $\hat{\alpha}_{i j}$. They are used to get rid of fixed effects in $\ln K_{i j t}$ by calculating $\ln \tilde{K}_{i j t}=\ln K_{i j t}-\hat{\alpha}_{i j}$. In the second step, we adopt a linear-inparameter specification and estimate the $\lambda$ th quantile function conditional on $\mathbf{X}$ and $\mathbf{Z}$ for nutrition by using equation (3) to obtain the residual $\hat{v}_{i t}$. As the third step, in equation (2), $\ln K_{i j t}$ is replaced by $\ln \tilde{K}_{i j t}$ and $\hat{v}_{i t}$ is plugged into the $\tau$ th quantile function conditional on $\mathbf{X}$ and $\mathbf{Z}$ to correct for the endogeneity. Thus, equation (2) becomes:

$$
Q_{\ln \tilde{K}_{i j t} \mid \mathbf{X}, \mathbf{Z}}(\tau \mid \mathbf{X})=\beta_{0}(\tau)+\beta_{1}(\tau) \ln y_{i t}+\mathbf{X} \boldsymbol{\beta}_{2}(\tau)+\beta_{3}(\tau) \hat{v}_{i t}+u_{i t}
$$


where $\lambda$ and $\tau$ range from 0.1 to 0.9 with an increment of $0.01{ }^{12}$ Consistent estimators are defined by

$$
\hat{\boldsymbol{\beta}}(\tau) \equiv \underset{\boldsymbol{\beta} \in \Theta}{\arg \min } \mathrm{E}_{n T}\left[\rho_{\tau}\left(\ln \tilde{K}_{i j t}-\hat{\beta}_{1} \ln y_{i t}-\mathbf{X} \hat{\boldsymbol{\beta}}_{2}-\hat{\beta}_{3} \hat{v}_{i t}\right)\right]
$$

$\hat{\beta}_{1}(\tau)$ picks up the heterogeneous impact of income on nutrient at each quantile $\tau$. Other distribution-sensitive nutritional effects are included in the vector $\hat{\boldsymbol{\beta}}_{2}(\tau)$. A significant $\hat{\beta}_{3}(\tau)$ indicates the existence of endogenous income. The assumption underpinning this three-step estimation strategy is that the impact of household unobserved and time-invariant heterogeneity on nutritional outcomes is same across quantiles.

\section{Results}

\subsection{Identifying the determinants of urban and rural households' nutrient intake}

Tables 1 and 2 summarise the results on key variables based on the unbalanced panel with household fixed effects for urban and rural areas, respectively. Two instruments perform well in all columns: they are jointly significantly different from zero in explaining household income according to $F$-statistics, which indicates that the instruments are not weak. In the first stage, as expected, the 'proportion of farmland suffering from natural disasters' is negative and significant and the 'growth rate of provincial average wage' is positive and significant, as shown at the bottom of Tables 1 and 2 . The matrix of reduced form coefficients has full rank according to the Anderson LM test, indicating equation (1) is identified. The instruments are uncorrelated with the error term according to Sargan-Hansen test. This shows that there is no overidentification problem, or exclusion restrictions are satisfied.

\section{[Tables 1 and 2 to be inserted]}

\footnotetext{
${ }^{12}$ The values of $\lambda$ and $\tau$ can be different, but we equated them for simplicity.
} 
Columns 1-4 of Table 1 show positive and significant impact of income on total calorie intake (with the elasticity estimate 0.10 ) and three macronutrients except fat for which the impact is positive but statistically insignificant. ${ }^{1314}$ The income elasticity of protein $(0.14)$ is slightly higher than that of carbohydrate $(0.12) .{ }^{15}$ If we use a full sample ( 8 waves) to estimate the fixed-effects IV model with selective explanatory variables, we also find a positive income effect on total calorie intake with the elasticity estimate of 0.11 (Appendix 3). However, the income elasticity of protein $(0.11)$ is lower than that of fat $(0.16)$, but higher than that of carbohydrate (0.05). These are statistically significant except for carbohydrate. Overall, income growth of urban households has led to more intake of fat and protein in the longer term.

In rural areas log of household per capita net income is negatively and significantly associated with 'total calorie' and 'protein' (Columns 1 and 4 of Table 2). This appears to be counter-intuitive at first sight, but further investigation of the data would allow us to make the following observations. First, the result appears to be influenced by the households whose income lies just above the median income. If we split the households into quantiles in each

\footnotetext{
${ }^{13}$ We re-estimated Tables 1 and 2 with only income and household demographic characteristics, by dropping most of other control variables. While the overall pattern of the results is similar, the income effect loses its statistical significance, except in the case of protein for urban households (positive and significant) and carbohydrate (negative and significant) for rural households. These results are available on request. We have decided to report the cases with a full set of covariates in Tables 1 and 2 as they are not highly correlated with other variables and we focus on household heterogeneity.

${ }^{14}$ As a robustness check we have also applied OLS to the pooled cross-sectional data without household fixed effects (see Appendix 2). For urban households, the income effect loses statistical significance in OLS with a smaller coefficient estimate. For rural households, while the IV estimation shows a negative relationship between income and nutrient intake, the relation becomes positive in OLS. We have decided to report only IV results because (i) the Wu-Hausman-Durbin test strongly favours IV model over OLS for both urban and rural cases and (ii) the specification tests for IV reported in Tables 1 and 2 imply that the instruments are valid.

${ }^{15}$ In the existing literature on China, nutrient elasticities are much smaller than food demand elasticities of income (Tian and $\mathrm{Yu}, 2013)$. One explanation could be the switch from quantity to quality and/or tastes, or a switch to more expensive sources of calories. While the data of food quality are unavailable, we use indirect evidence. The household's average frequency of using processed food in meal preparation over last 3 days has increased at an annual growth rate of $3.1 \%$, while the frequency of eating out at restaurants has also risen to $7.6 \%$. We have re-estimated the model in Tables 2 and 3 by replacing the dependent variable by these variables. We have found a statistically significant association between higher income and higher frequencies of eating in restaurants for urban households, while income is not statistically significant in other cases.
} 
wave according to their per capita income and calculate the change of total calorie intake and three macronutrients, then the third quartile is found to have experienced the largest decline in total calorie intake (especially between 2004 and 2006, -3.3\%) and protein consumption (3.3\%) than other quartiles. Second, using the CHNS, Zhao et al. (2013) ascribed declining total calorie intake between 1991 and 1997 to a significant drop in protein. Third, another reason might be the shift of energy source towards fat rather than protein, as households consume more westernised food (e.g., fast food and snacks). We calculated the average nutrient intake at each level of physical activity. The highest level of fat (except 1989) and only moderate protein were consumed by those with a decent job and at the lowest intensity of occupation-based physical activity. ${ }^{16}$ Finally, if protein intake is already high among a large segment, as suggested by the aforementioned protein intake figures (where per equivalent adult per day declined from $100 \mathrm{~g}$ to $87 \mathrm{~g}$ in $1989-2009$, but was above the WHO's threshold of $66 \mathrm{~g}$ ), the positive relation between income and protein could weaken or get reversed. ${ }^{17}$

Intensified physical activity increases households' fat consumption only in urban areas (Column 2 of Table 1). ${ }^{18}$ In comparison, rural households engaged in more physically intensive occupations would consume more carbohydrate and thus, consume more calorie and carbohydrate (Columns 1 and 3 of Table 2). Both out-migration and local off-farm

\footnotetext{
${ }^{16}$ As an extension, we have re-estimated Tables 1 and 2 to investigate which sub-component of income (namely, agriculture, household business, and wage income) is linked to the relationship between income and nutrient intake. It should be noted that different sources may also be linked to different calorie requirements depending on how strenuous the work is (Deaton and Dreze 2009). For rural households, increase in the share of crop income in total income increases their total energy intake - as well as carbohydrates and protein - at the $10 \%$ significance level. For urban households, net business and wage incomes significantly increase nutrient intake. These results are available on request.

${ }^{17}$ As shown in Appendix 3, if we use the data covering 1989-2009, income effect on protein intake for rural sample is positive and significant with the coefficient estimate similar to that for urban sample (0.11). It is conjectured that a positive income effect on protein tuned negative after 2004. The income effect is significant and positive for total calorie intake of rural households (0.08), mainly driven by a large and significant elasticity estimate of carbohydrate in 1989-2009.

${ }_{18}$ Average weight has increased gradually in 1991-2009, while the intensity of physical activity has declined during the same period for all age groups (Appendix 4). The coefficient estimate of income on nutrient intake is largely same regardless of whether physical intensity is included in our estimations.
} 
employment lead to higher intake of carbohydrates, protein and total calories (Columns 1, 3 and 4 of Table 2). The magnitude of the impact of local off-farm employment is significantly larger than that of out-migration only in the case of protein.

Food prices appear to be one of the main sources for differences in both urban and rural households' nutrient intake. In Table 1, urban households' intake of total calorie and macronutrient intakes are not affected by the level of prices of cereals, but would be lowered by higher prices of meat and eggs. The magnitude of these negative effects is large: a one percentage point increase in the meat (egg) price index could reduce the household's total energy intake by $3.37 \%(1.57 \%)$ in Column 1 of Table 1 . The reduction of energy intake caused by the rising meat price originates from all three macronutrients, especially fat $(-4.11 \%$ in Column 2 of Table 1), while that caused by a higher egg price comes from carbohydrates ($2.08 \%$ in Column 3 of Table 1). Higher vegetable prices are associated with more energy intake (1.04 in Column 1 of Table 1) through their positive impact on fat (Column 2 of Table 1). A reason underlying the above changes in demand for nutrients could be the relative price changes as mentioned by Deaton (1997). The community survey of the CHNS shows that both the level and proportional increases in the prices of meat and eggs are higher than those of rice, flour and vegetables (Zhai et al., 2014). Households might have thus substitute vegetables for meat and eggs as the former are less expensive than the latter. An example supporting this explanation can be found during the food crisis (2007-2008). The data from China Urban Life and Price Yearbook published annually by the National Bureau of Statistics show that an average urban household kept consuming more vegetables on a per capita basis at the annual growth rate of $4.5 \%$ during the food crisis, while less beef $(-14.3 \%)$, lamb (-9\%), eggs $(-0.8 \%)$, and dairy products $(-14.4 \%)$. Uncertainty in terms of volatilities of prices of cereals and 'fat and oil' does not negatively affect urban households' total energy intake, but decreases fat intake. Volatilities in vegetable prices decrease total energy intake through its 
negative impact on carbohydrates (Columns 1 and 3 of Table 1). A large positive effect has been found for egg price volatilities on carbohydrate (5.9 in Column 3 of Table 1). There appears to be considerable substitution of starchy foods or staples for eggs under the price shock of eggs.

On the contrary, Table 2 shows that rural households would consume more fat, carbohydrates and protein under higher egg prices and thus, more total energy. Higher fat and oil prices are associated with more consumption of fat and carbohydrates. A higher price of vegetables suppresses carbohydrates and protein but promotes fat intake. As a result, total energy is not responsive to it. We have consistently found positive coefficient estimates of volatility of meat price on intake of total calorie and all three macronutrients with considerably large magnitudes (varying from 3.53 for carbohydrate in Column 3 to 12.1 for fat in Column 2). This may be driven by rural households' strong preferences for meat.

Overall, households' demand for nutrients appears not to respond to the price changes of staple food, but to more expensive items, such as meat, eggs and vegetables. The reason from the demand side is that grains still dominate rural households' diet and are the second food source for urban households. From the supply side, the Chinese government has long smoothed domestic prices of grains by various administrative means, such as price regulation, import protection, limiting export (Jansen and Miller, 2008), and agricultural subsidies (Huang et al., 2013). These policies also promote grain yields which have increased continuously for more than a decade since 2003 and help stabilise their prices during the international food price spike in 2008 (World Bank, 2012). By contrast, the price of meat escalated by $24 \%$ during the food crisis between 2007 and 2008 due to the increased cost of inputs, such as raw materials and agricultural wages (You, 2014).

Consistent with Shimokawa (2013), acquiring more knowledge of healthy diet does not necessarily raise nutrient intake, except for fat among rural households (Column 2 of Table 2), 
as indicated by insignificant coefficients estimates of 'dietary knowledge' in Tables 1 and 2. Using the CHNS (2000-2006), Shimokawa (2013) finds that the nutritional impact of dietary knowledge hinges on one's expectation about food availability (EFA). Dietary knowledge lowers total calorie intake (a quantity effect) when EFA is increasing and lowers the share of calories from oil (a quality effect) when EFA is decreasing. The former is larger among the overweight adults, while the latter matters more among the non-overweight. He found that the effect of dietary knowledge tends to be small without differentiation of these heterogeneities. The impact of dietary knowledge might also relate to which sort of information has been delivered. The randomised controlled trials conducted by Luo et al. (2012) do not show any significant reductions in child anaemia as a result of either single or multiple face-to-face health education programmes with written education materials distributed. By contrast, using the CHNS (1997-2004), Zhao et al. (2013) document the effects of information on own health status (i.e., receiving hypertension diagnosis) on reducing fat intake. The switch in preferences towards energy - and sugar-rich diet, or doing more physical exercises, seems to be irrelevant for higher nutrient intake for both urban and rural households. These apparently counter-intuitive findings are subject to heterogeneity across households in different levels of nutrient intake. This is investigated in the next subsection.

\subsection{Distributional effects within urban and rural areas}

We proceed to examine the distributional effects for urban and rural households in Tables 3 and 4, respectively, by using IV quantile regressions with household fixed effects. We have found that the income elasticities of carbohydrates and protein for urban households are positive (Table 1). However, Columns 4 and 7 of Table 3 show that this significant relation is observed only at the bottom $10^{\text {th }}$ percentile of the distribution of each nutrient and at the 
median of protein. Elasticity estimates are statistically insignificant at the median and at the $90^{\text {th }}$ percentile for carbohydrates and at the $90^{\text {th }}$ percentile for protein. As coefficient estimates tend to get much larger, positive and more statistically significant at lower percentiles, overall income growth would help alleviate inequality of distributions of carbohydrates and protein among urban households. ${ }^{19}$

\section{[Tables 3 and 4 to be inserted]}

Higher prices of meat tend to reduce urban households' nutrient intake, except for those who have consumed much carbohydrate (Column 6 of Table 3). Acquiring food knowledge is found to increase significantly all three macronutrients for those with relatively high nutrient intake (at the median and the $90^{\text {th }}$ percentile), in contrast to the standard IV results where it is statistically insignificant in Tables 1 and 2. Preference for doing exercises ('activity preference') increases fat and protein intakes for those with moderate or larger intake of each nutrient, reflecting the larger nutrient demand of those who are doing relatively more exercises. But it decreases carbohydrates and protein for those at the bottom $50 \%$ of the distribution of intake of these macronutrients. The mixed results may be driven by the fact that the variable captures only the extent of 'likeness' expressed by household members, rather than the real time for exercises. Overall, insignificant coefficient estimates of acquiring food knowledge or 'activity preference' in the standard IV estimation do not reflect the heterogeneity across distributions of household intake of each nutrient. On the community variables (omitted from the table), transport and health services benefit those with at least moderate fat or carbohydrate intake, while social services are in general associated with

\footnotetext{
${ }^{19}$ Compared with young households aged below 30, those with the average age of household members between 30 and 40 years and with moderate nutrient intake, consume more carbohydrate and protein, while among the older, the intake decreases at a faster speed. In contrast, the households with the least nutrient intake only experience the negative impact of aging, especially among the cohorts aged above 40 . These results are omitted from Table 3 . Among those with relatively high nutrient intake, belonging to the ethnic minority group is associated with lower intake of fat, carbohydrate, and protein, presumably because of specific cultural factors conditioning their diets.
} 
nutrition improvement for those with the lowest or moderate fat, carbohydrate, or protein intake.

For rural households, overall income growth would also help reduce inequality in the distribution of macronutrient intake (i.e. fat, carbohydrate and protein). This is because for all the three nutrients a link between income and nutrient intake is found to be significantly negative and stronger at the $90^{\text {th }}$ percentile of the distribution than any other lower percentile points (Table 4). Out-migration can increase rural households' fat intake for those with low fat or protein consumption (Columns 1-2 and 7-8 of Table 4), and this impact is proportionally large for those with the least nutrient intake. Rural households' carbohydrate intake increases with out-migration regardless of their existing carbohydrates intake level (Column 4-6 of Table 4). Similarly, local off-farm employment is positively correlated with higher carbohydrate and protein intake for the entire distribution of these nutrient intakes. However, this will not increase fat intakes for those at the lowest fat intake level. Ethnic minorities tend to consume less fat and protein regardless of their position in the nutrient intake distribution. This reflects a particularly severe nutrition status for the rural ethnic minorities. Education tends to increase carbohydrate and protein intake regardless of the level of intake of each nutrient.

To report the effects of prices selectively, fat intake of rural households would be reduced by higher and more volatile meat prices, lower and less volatile vegetable prices and lower cereal prices. Carbohydrate intake would be reduced significantly by higher cereal and vegetable prices (and the fluctuations of the latter) among those who consume it moderately. Higher meat prices tend to reduce protein intake of rural households for those who consume it at least moderately. As in urban cases, acquiring knowledge on healthy diet will raise rural households' fat and protein consumption regardless of their positions in the distribution of current intake levels. 
The results presented in Tables 3 and 4 suggest that (i) households' responses to income increase and other factors is different depending on the level of their nutrient intake and (ii) overall income growth would reduce inequality in distribution of nutrient intake.

\subsection{Implications for nutrition poverty}

Following Park and Wang (2001), 'nutrition poverty' is measured using the cut-off of 2,100 kcal per person per day where the FGT class of poverty indices are computed (Figure 3). The nutrition poverty headcount rate $(\mathrm{FGT}(0))$, nutrition poverty gap (FGT(1)) and its square (FGT(2)) all increased in both urban and rural areas. Meanwhile, the remaining income poor have to confront the dual burden of both income poverty and nutrient deficiency, which could result in a nutrition-poverty trap in the long term.

\section{[Figure 3 to be inserted]}

Using the specification of equation (1), we have regressed nutrition poverty measures as a dependent variable instead of nutrient intake. First, despite a positive impact of income on nutrient intake for urban households, income growth does not exhibit a statistically significant effect in reducing the incidence of nutrition poverty or narrow the nutrition poverty gap, but alleviates the severity of nutrition poverty. On the other hand, for rural households, income growth would increase the probability of falling below the nutrition poverty line. Broadly similar results are obtained for an alternative poverty line at 2,400 kcal per person per day, but in this case income significantly reduces all classes of poverty for urban households. Urban households' nutrition poverty responds positively to rising meat prices (Columns 1-3 of Table 5). This poverty-increasing effect is also observed for rural 
households. However, in this case, nutrition poverty is more negatively related with higher prices of 'fat and oil' and eggs (Columns 4-6 of Table 5). ${ }^{20}$

\section{[Table 5 to be inserted]}

\subsection{Obesity and undernourishment}

Despite the threat of increasing nutrition poverty for some households, obesity has become a major concern in both urban and rural areas. Our data show that the overall prevalence of obesity, or the obesity rate, increased from $2.5 \%$ in 1989 to $4.4 \%$ in 2009 , consistent with Gordon-Larsen et al. (2014). ${ }^{21}$ As shown in Figure 4, the obesity rate is particularly high and has increased sharply after 2000 among children (0-19 years old) and has increased over time across different age groups.

\section{[Figure 4 to be inserted]}

First, Column 3 of Tables 3 and 4 suggest a few implications for the determinants of obesity as it could be conjectured that households with more intake of fat are more likely to have obese members given the association between fat intake and obesity in China (e.g. Chunming, 2000). In both urban and rural areas, obesity - proxied by higher intake of fat - is associated with lower intensity of physical activity. It increases with less expensive meat and with more expensive vegetables, as well as with lower fluctuation in prices of vegetables only for rural areas - and cereals (see Section 4.2).

\footnotetext{
${ }^{20}$ A few important points should be noted from the results not reported in Table 5. First, we have found that the community development in terms of better transport, social services and local economic prosperity, helps combat rural nutrition poverty. On the other hand, urban households benefit only from social services in reducing the incidence of nutritional deprivation. Second, the average age of household members is associated with nutrient deficiency, as evidenced by the statistically significant and positive coefficient estimates for the households whose average age is above 50 years and those in retirement age cohort (above 60 years) with a much higher coefficient for the latter. For instance, those in retirement age are 16.4\% more likely to be in nutrition poverty. These results still hold under the nutrition poverty line of 2,400 kcal per person per day.

${ }^{21}$ Obesity has also become prevalent in India to a lesser degree, with the overall rate of obesity of $3.2 \%$ in 2005 (Gaiha et al., 2014b). However, there are strong grounds for a rapid rise in obesity in recent years.
} 
Second, using the same set of explanatory variables, we carry out supplementary analyses where the dependent variable in Tables 1 and 2 is replaced by a proxy for obesity defined as whether a household has any member with BMI-for-age>+2SD - which is equivalent to 30 $\mathrm{kg} / \mathrm{m}^{2}$ at 19 years old - according to the WHO's criteria. All pregnant women are excluded. Undernourishment is defined by using the threshold of 'BMI-for-age<-2SD'. ${ }^{22}$ Here the model is estimated by maximum likelihood using a household random-effects panel probit $\operatorname{model}^{23}$ where household income is estimated by the same set of instruments in the first stage, as before, to take account of the endogeneity of income. We adopt the same set of explanatory variables as in Tables 1 and 2. It should be noted that the data on height and weight are available only for a subset of households in this supplementary analysis. A selective summary of the results is given below.

\section{[Table 6 to be inserted]}

Contrary to the case of 'fat' for rural areas where income significantly decreases fat intake at the $90^{\text {th }}$ percentile point (Columns 3 of Table 4), income effect is not significant for obesity for rural areas in Column 4 of Table 6. A statistically significant income effect is not found for undernourishment or obesity in either rural or urban areas. Also, unlike the results in Column 3 of Tables 3-4, obesity is insensitive to the intensity of physical activity, while both higher intensity of physical activity and preference for exercises tend to decrease undernourishment in rural areas. It is notable that higher average education of household members tends to reduce both obesity and undernourishment rates in rural areas, but only the obesity rate in urban areas. In urban areas, rise of cereal prices will reduce the prevalence of obesity, while increasing undernourishment.

\footnotetext{
${ }^{22}$ The analysis of obesity requires anthropometric data for the individual panel data taking account of personal history of dietary patterns as well as observable and unobservable characteristics. This is beyond the scope of the present study.

${ }^{23}$ Random-effects probit model is used because fixed-effects logit model drops a considerable number of households with the same observations ( 0 or 1$)$ over the years.
} 
In urban areas, obesity is negatively associated with higher prices of fat and oil as well as cereals, while undernourishment is positively associated with cereals prices. However, price volatilities are not statistically significant. In rural areas, fluctuations in prices of cereals and meat would increase the prevalence of undernourishment. Preference for fast food actually worsens undernourishment in rural areas, while undernourishment would be alleviated by household members' preference for exercises in rural areas. However, it would have an opposite effect in urban areas. The reason for this is not clear, but this could be explained by the rural-urban difference in terms of the relationship between exercise and fat intake. Rural households with low or medium fat intake tend to reduce fat intake further if they prefer more exercises, while urban households would increase fat intake by their preference for exercise (Columns 1 and 2 of Tables 3 and 4).

Based on these supplementary analyses, we can conclude that (i) a higher income will decrease fat intake of households with a higher fat intake in rural areas, but it will not influence obesity or undernourishment, and (ii) food prices and fluctuations are important determinants of obesity as well as undernourishment.

\section{Conclusion}

This study has examined a number of factors in determining Chinese households' nutrient intake over two decades (1989-2009). A point of departure of the present study is to model (i) heterogeneity in the effect of household income on nutrient intake, and (ii) the endogeneity of household income to provide a robust estimate for the effect of income on nutrient intake at its different levels. To do this, we have combined recent seminal works by Canay (2011) and Lee (2007) to estimate the quantile instrumental variable (IV) fixed-effects panel model. Supplementary analyses were carried out for undernourishment and obesity. 
As income keeps rising, households with moderate or higher macronutrient intake tend to decrease their macronutrient intake - especially fat - in rural areas, while the least nourished tend to consume more carbohydrates and protein in urban areas in case we use the panel data in 2004-2009. ${ }^{24}$ Thus, income growth is likely to reduce inequality in the distribution of nutrient intake among households in both rural and urban areas in 2004-2009. However, an effect of reducing inequality is not found for household nutritional status, defined by whether a household has any undernourished or obese member.

Education, dietary knowledge or preferences of eating and physical exercise seem unimportant for household nutrient intake, but this calls for further investigation with alternative proxies and dietary measures given the limitations of our data. Only households with more nutrient intake in urban areas are able to benefit from access to dietary knowledge. Furthermore, uncertainties in terms of soaring and volatile food prices that have recently been observed all over the world suggest substantial but different effects on household nutrient demand, varying with specific food commodities. It is conjectured that in urban areas, the positive income effect on nutrient intake, or the nutrition-poverty reducing effects of income, is weak and other factors, such as, increases in food prices and their volatilities (e.g. meat) and aging, can easily offset the weak income effects. Higher food prices and their fluctuations may have resulted in higher nutrition poverty despite high income growth of urban households. This is confirmed by our supplementary analyses of undernourishment and obesity.

In rural areas, the aggregate household income effect on nutrient intake is negative. As the average household income goes up, the proportion of the households which are below the nutritional-intake poverty threshold tends to increase unless they have access to out-migration

\footnotetext{
${ }^{24}$ It should also be noted that as income rises, diet diversification rises and as a result of preference for taste there is a switch towards more expensive sources of calories and a fall in calorie intake (Gaiha et al., 2014a).
} 
or local off-farm employment, or alternatively, significantly increases the share of crop income in the total income. Overall, the pattern of income growth, rising food prices and their volatilities appear to jointly explain the paradoxical rising income and declining nutrient intake in China.

Turning to policy implications, agriculture still plays a key role in improving rural households' nutrition if the policy makers take advantage of positive loops between income and nutrition. However, policies promoting income growth alone may not be sufficient to raise household nutrient intakes, as the poor, especially in urban areas where people also face nutrition deficiency because of aging, do not seem to enjoy the benefit of income growth. Certain traditional recipes alone, such as promoting education, may not be effective in the Chinese context. Interventions have to be tailored to serve better urban and rural population, respectively. For the former, more pro- (nutritionally) poor income growth would enhance nutrient intake and narrow nutrition inequality between households to some extent. For the latter, growth of crop income is of paramount importance. Moreover, community development is also a policy instrument to promote rural household nutrients' intakes. For both urban and rural populations, the policies stabilising income streams and helping cushion against the risks of soaring and volatile prices of food commodities would generate substantial positive impact on household nutrition status. 


\section{References}

Bishop, J. A., Haiyoung, L., \& Buhong, Z. (2010). Rising incomes and nutritional inequality in China. In J. A. Bishop (Ed.). Research on Economic Inequality, (Vol. 18). Emerald Group Publishing Limited, pp.257-266.

Bliss, C. J., \& Stern, N. H. (1978). Productivity, wages and nutrition: Part I: The Theory. Journal of Development Economics, 5, 331-362.

Bloom, D. E. (2011). 7 Billion and counting. Science, 333, 562-569.

Bloom, D.E., Canning, D., \& Lubet, A. (2015). Global Population Aging: Facts, Challenges, Solutions and Perspectives. Daedalus, 144(2), 80-92.

Bui, A.T., Dungey, M. Nguyen, C. V., \& Pham, T. P. (2014). The impact of natural disasters on household income, expenditure, poverty and inequality: evidence from Vietnam. Applied Economics, 46(15), 1751-66.

Canay, I. A. (2011). A simple approach to quantile regression for panel data. Econometric Journal, 14(3), 368-386.

Carter, C. A., \& Zhong, F. (1999). Rural wheat consumption in China. American Journal of Agricultural Economics, 81, 582-592.

Chamon, M., Liu, K., \& Prasad, E. (2013). Income uncertainty and household savings in China. Journal of Development Economics, 105, 164-177.

Chen, C. (2014) The current nutritional status in China. In Improving Diets and Nutrition: Food-Based Approach. B. Thompson and L. Amoroso (eds). FAO and CABI. pp. 89100.

Chen, S., \& Ravallion, M. (2010). China is poorer than we thought, but no less successful in the fight against poverty. In S. Anand, P. Segal, \& J. E. Stiglitz, (Eds.), Debates on the Measurement of Global Poverty, Oxford: Oxford University Press. 
Chunming, C. (2000). Fat intake and nutritional status of children in China. The American Journal of Clinical Nutrition, 72(5), 1368s-1372s.

Dasgupta, P. (1997). Nutritional status, the capacity for work, and poverty traps. Journal of Econometrics, 77, 5-37.

Deaton, A. (1997). The analysis of household surveys: A microeconometric approach to development policy. Baltimore and London: The Johns Hopkins University Press.

Deaton, A., \& Dreze, J. (2009). Food and nutrition in India: Facts and interpretations. Economic and Political Weekly, XLIV(7), 42-65.

Du, S., Mroz, T. A., Zhai, F., Popkin, B. M. (2004). Rapid income growth adversely affects diet quality in China - particularly for the poor! Social Science \& Medicine, 59, 15051515.

FAO (2003). Food energy - methods of analysis and conversion factors (FAO Food and Nutrition Paper 77). Rome: FAO.

FAO (2013). The state of food insecurity in the world: The multiple dimensions of food security. Rome: FAO.

Foster, J., Greer, J., and Thorbecke, E. (1984). A Class of Decomposable Poverty Measures. Econometrica, 52(3), 761-766.

Gaiha, R., Kaicker, N., Imai, K. S., Kulkarni, V. S., \& Thapa, G. (2014a). Dietary shift and diet quality in India: an analysis based on the 50th, 61st and 66th rounds of the NSS. In R. Jha, R. Gaiha, \& A. Deolalikar (Eds.). Handbook on Food: Demand, Supply, Sustainability and Security, Gloucestershire, UK: Edward Elgar Publishing.

Gaiha, R., Jha, R., and Kulkarni, V. S. (eds.) (2014b). Diets, Malnutrition, and Disease: The Indian Experience. New Delhi: Oxford University Press.

Gale, F., \& Huang, K. (2007). Demand for food quantity and quality in China (Economic Research Report No. 32). Washington DC: United States Department of Agriculture. 
Gordon-Larsen, P., Wang, H., \& Popkin, B. M. (2014). Overweight dynamics in Chinese children and adults. Obesity Reviews, 15(s1), 37-48.

Guo, X., Mroz, T. A., Popkin, B. M., \& Zhai, F. (2000). Structural change in the impact of income on food consumption in China, 1989-1993. Economic Development and Cultural Change, 48, 737-760.

Headey, D. D. (2013). Development drivers of nutritional change: A cross-country analysis. World Development, 42, 76-88.

Hovhannisyan, V., \& Gould, B. W. (2011). Quantifying the structure of food demand in China: An econometric approach. Agricultural Economics, 42, 1-17.

Huang, K. S., \& Gale, F. (2009). Food demand in China: Income, quality, and nutrient effects. China Agricultural Economics Review, 1, 395-409.

Huang, J., Wang, X., \& Rozelle, S. (2013). The subsidization of farming households in China's agriculture. Food Policy, 41, 124-132.

Jha, R. Gaiha, R., \& Sharma, A. (2009). Calorie and Micronutrient Deprivation and Poverty Nutrition Traps in Rural India. World Development, 37(5), 982-991.

Jones-Smith, J. C., \& Popkin, B. M. (2010). Understanding community context and adult health changes in China: Development of an urbanicity scale. Social Science \& Medicine, 71, 1436-1446.

Lee, S. (2007). Endogeneity in quantile regression models: A control function approach. Journal of Econometrics, 141, 1131-1158.

Luo, R., Shi, Y., Zhang, L., Zhang, H., Miller, G., Medina, A., \& Rozelle, S. (2012) The limits of health and nutrition education: Evidence from three randomized-controlled trials in rural China. CESifo Economic Studies, 58(2), 385-404.

Ma, H., Rae, A., Huang, J., \& Rozelle, S. (2004). Chinese animal product consumption in 1990s. Australian Journal of Agricultural and Resources Economics, 48, 569-590. 
Meng, X., Gong, X., \& Wang, Y. (2009). Impact of income growth and economic reform on nutrition availability in urban China: 1986-2000. Economic Development and Cultural Change, 57, 261-295.

Noy, I. (2009). The macroeconomic consequences of disasters. Journal of Development Economics 88, 221-231.

Park, A. \& Wang, S. (2001). China's poverty statistics. China Economic Review, 12, 384398.

Popkin, B. M., Du, S., Zhai, F., \& Zhang, B. (2010). Cohort profile: The China Health and Nutrition Survey - monitoring and understanding socio-economic and health change in China, 1989-2011. International Journal of Epidemiology, 39, 1435-1440.

Shimokawa, S. (2010). Nutrient intake of the poor and its implications of the nutritional effect of cereal price subsidies: Evidence from China. World Development, 38, 10011011.

Shimokawa, S. (2013). When does dietary knowledge matter to obesity and overweight prevention? Food Policy 38, 35-46.

Thomas, D. (1994). Like Father, like Son; Like Mother, like Daughter: Parental Resources and Child Height. Journal of Human Resources, 29(4), 950-988.

Tian, X., \& Yu, X. (2013). The demand for nutrients in China. Frontiers of Economics in China, 8(2), 186-206.

World Bank (2014). World Development Indicators 2014. Washington DC, : World Bank.

You, J. (2014). Dietary change, nutrient transition and food security in fast growing China. In R. Jha, R. Gaiha, A. B. Deolalikar (Eds.) Handbook on Food: Demand, Supply, Sustainability and Security. Cheltenham, UK: Edward Elgar Publishing.

You, J., Wang, S., \& Roope, L. (2014). Multi-dimensional intertemporal poverty in rural China. CSAE Working Paper Series, No. 36, University of Oxford. 
Zhai, F. Y., Du, S. F., Wang, Z. H., Zhang, J. G., Du, W. W., \& Popkin, B. M. (2014). Dynamics of the Chinese diet and the role of urbanicity. Obesity Reviews, 15(S1), 1626.

Zhang, B., Zhai, F. Y., Du, S. F., \& Popkin, B. M. (2014). The China Health and Nutrition Survey, 1989-2011. Obesity Reviews, 15(S1), 2-7.

Zheng, Z., \& Henneberry, S. R. (2010). The impact of changes in income distribution on current and future food demand in urban China. Journal of Agricultural and Resource Economics, 35, 51-71.

Zhao, M., Konishi, Y., \& Glewwe, P. (2013) Does information on health status lead to a healthier lifestyle? Evidence from China on the effect of hypertension diagnosis on food consumption. Journal of Health Economics, 32, 367-385. 
Figure 1 Nutrient transition

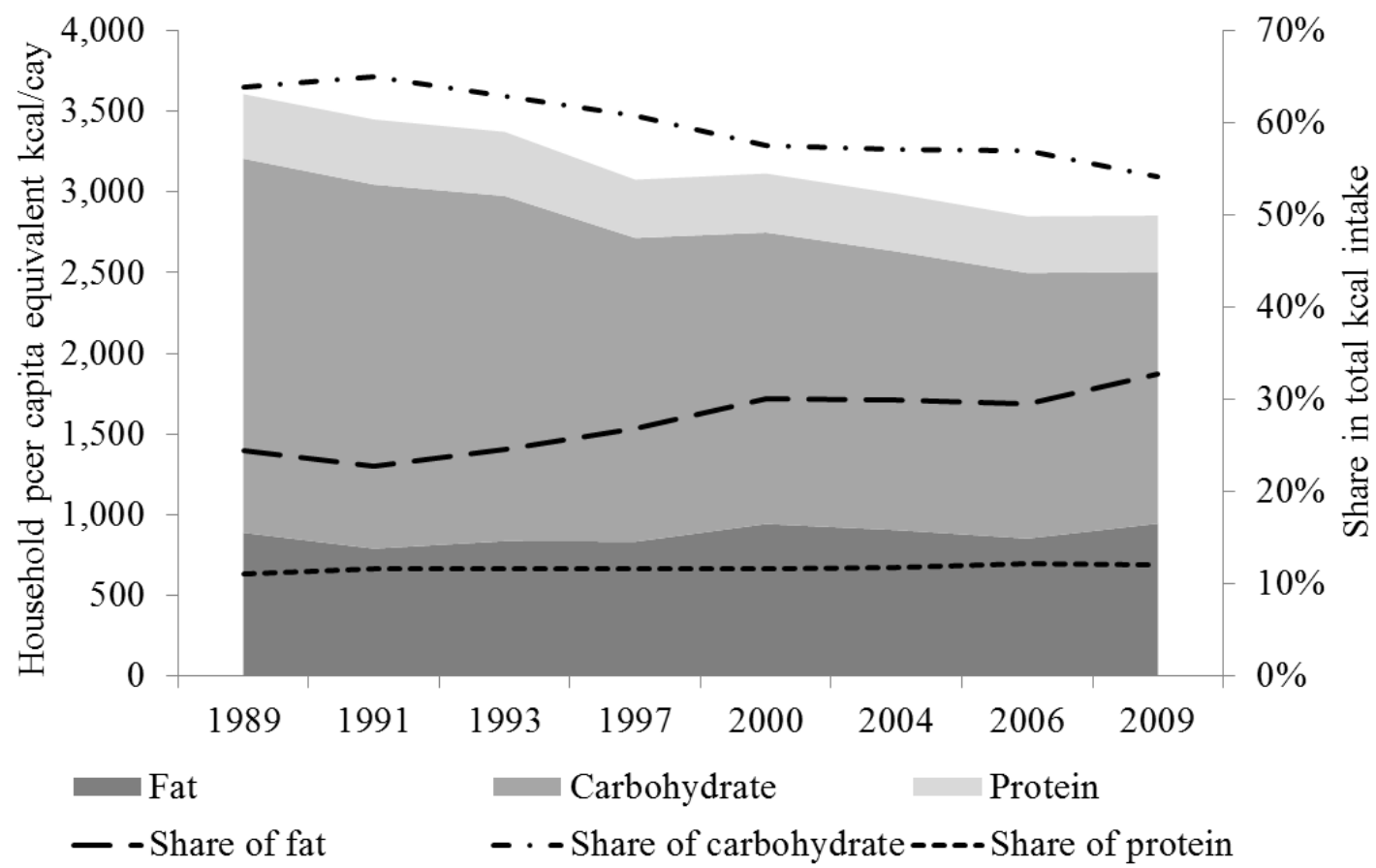

Source: Authors' calculation based on the CHNS.

Figure 2. Household average intensity of physical activity

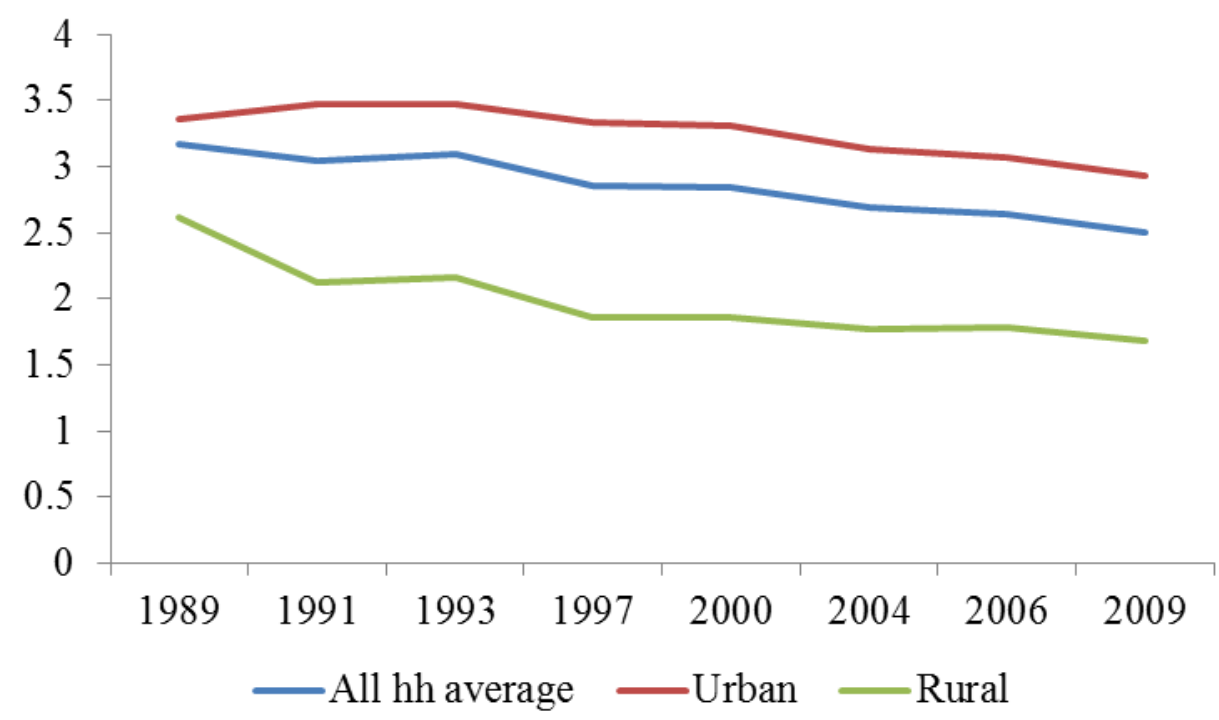


Figure 3 Nutrition poverty profile
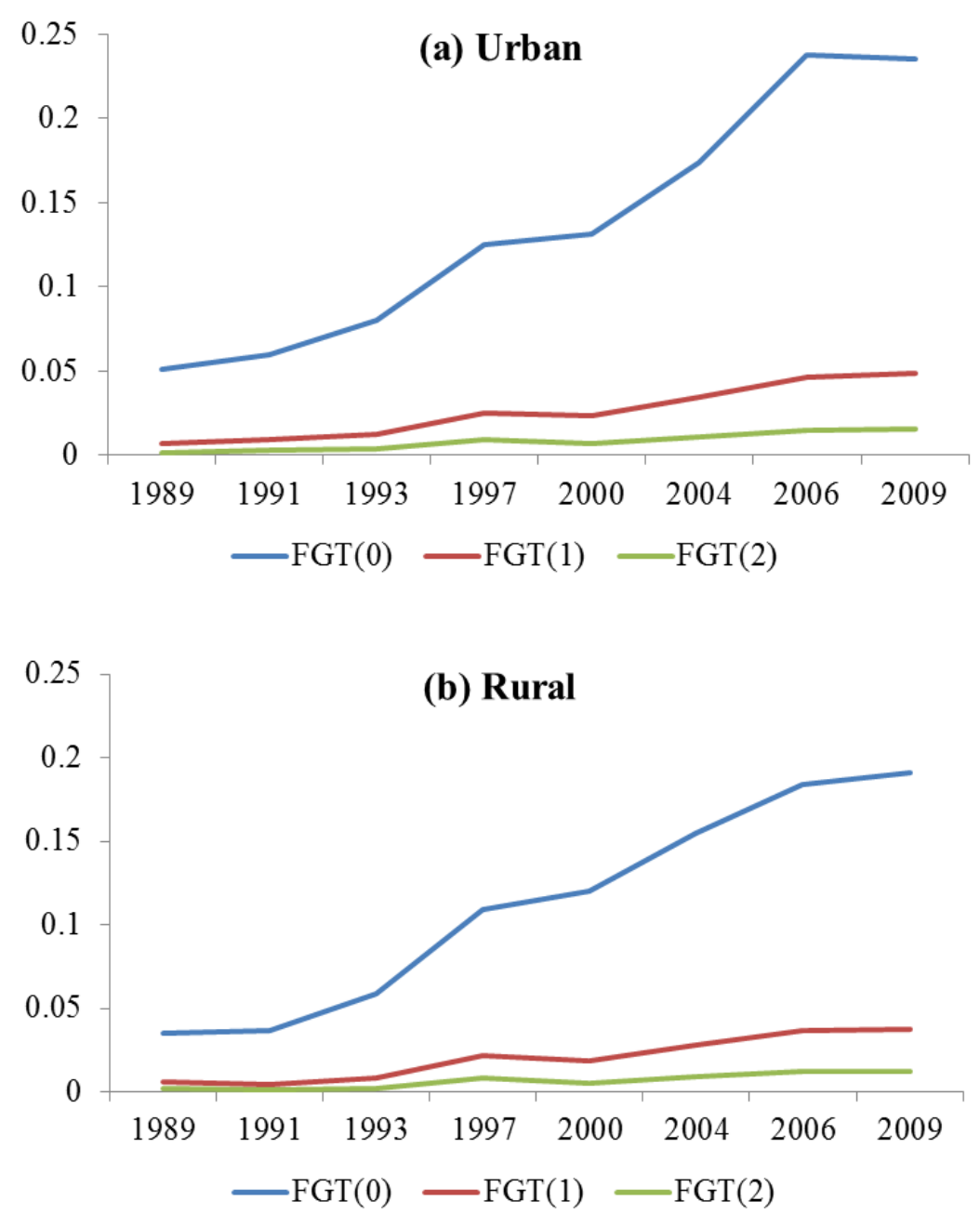

Source: Authors' calculation based on the CHNS.

Note: FGT(0), FGT(1) and FGT(2) represent the Foster-Greer-Thorbecke (1994) class of poverty measures, namely poverty incidence, poverty gap and squared poverty gap. Poverty here is defined as the household per capita equivalence total calories intake per day being less than $2,100 \mathrm{kcal}$. The vertical axis denotes percentage points and the horizontal axis shows year.

Figure 4. Obesity prevalence (by age cohort, excluding pregnant females)

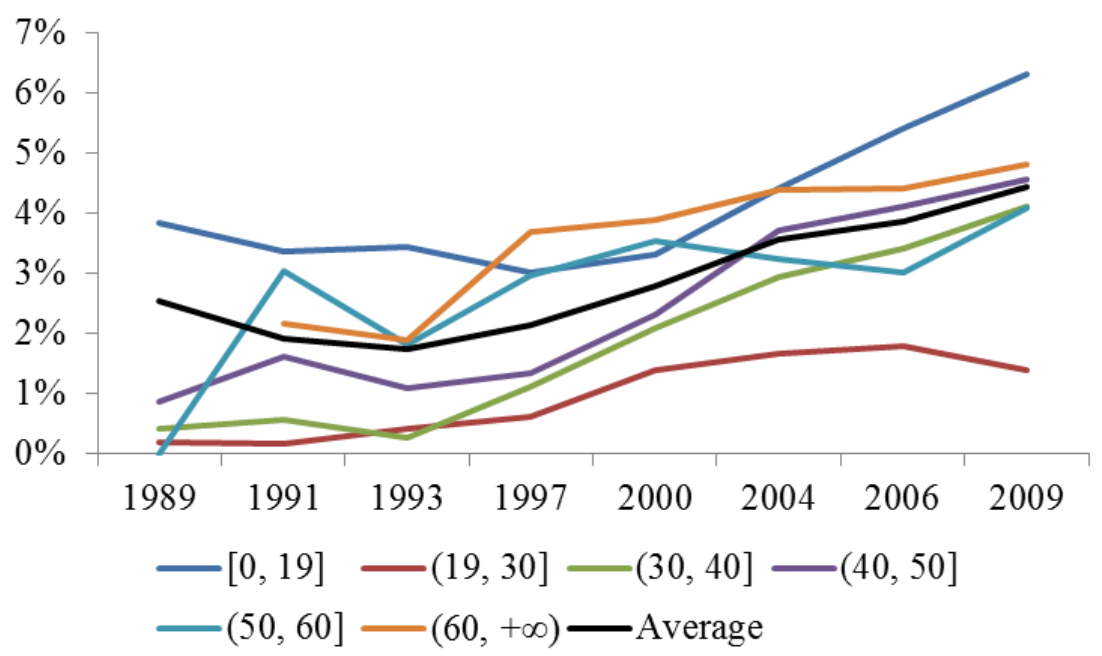

Source: Authors' calculation based on the CHNS. 
Table 1 Determinants of household nutrient intake (urban)

\begin{tabular}{|c|c|c|c|c|}
\hline \multirow{2}{*}{ Independent variable } & Total calorie & Fat & Carbohydrate & Protein \\
\hline & $(1)$ & $(2)$ & (3) & $(4)$ \\
\hline \multicolumn{5}{|l|}{ Income } \\
\hline $\begin{array}{l}\text { Ln(Household per capita net } \\
\text { income equivalent adult) }\end{array}$ & $0.097(0.043)^{* *}$ & $0.047(0.052)$ & $0.119(0.050)^{* *}$ & $0.138(0.054)^{* *}$ \\
\hline \multicolumn{5}{|l|}{ Occupation physical activity } \\
\hline Physical activity level & $-0.005(0.016)$ & $0.037(0.019)^{*}$ & $0.020(0.018)$ & $-0.007(0.021)$ \\
\hline Ethnicity & $0.048(0.115)$ & $0.100(0.154)$ & $-0.011(0.160)$ & $0.076(0.156)$ \\
\hline Education & $-0.029(0.031)$ & $-0.039(0.037)$ & $-0.021(0.037)$ & $-0.027(0.038)$ \\
\hline \multicolumn{5}{|l|}{ Level of food price } \\
\hline Cereals & $1.015(1.091)$ & $2.175(1.439)$ & $0.798(1.273)$ & $0.288(1.310)$ \\
\hline Fat and oil & $0.144(0.381)$ & $0.506(0.516)$ & $0.251(0.435)$ & $0.084(0.465)$ \\
\hline Meat & $-3.374(1.103)^{* * *}$ & $-4.114(1.404)^{* * *}$ & $-2.893(1.295)^{* *}$ & $-2.527(1.294)^{*}$ \\
\hline Eggs & $-1.569(0.821)^{*}$ & $-0.904(1.070)$ & $-2.075(0.995)^{* *}$ & $-1.418(0.989)$ \\
\hline Vegetables & $1.038(0.546)^{*}$ & $1.393(0.667)^{* *}$ & $0.893(0.633)$ & $0.455(0.660)$ \\
\hline \multicolumn{5}{|l|}{ Volatility of food price } \\
\hline Cereals & $-1.905(1.692)$ & $-4.607(2.274)^{* *}$ & $-1.190(1.906)$ & $0.970(2.148)$ \\
\hline Fat and oil & $-0.741(0.942)$ & $-3.538(1.299)^{* * *}$ & $0.176(1.114)$ & $-1.967(1.122)^{*}$ \\
\hline Meat & $2.280(1.822)$ & $3.072(2.315)$ & $1.549(2.032)$ & $2.259(2.185)$ \\
\hline Eggs & $4.706(3.072)$ & $0.746(3.938)$ & $5.899(3.503)^{*}$ & $4.469(3.662)$ \\
\hline Vegetables & $-1.210(0.719)^{*}$ & $-0.792(0.876)$ & $-1.665(0.835)^{* *}$ & $-0.475(0.876)$ \\
\hline \multicolumn{5}{|l|}{ Food knowledge } \\
\hline Chinese diet knowledge & $0.025(0.025)$ & $0.029(0.032)$ & $0.037(0.029)$ & $0.024(0.024)$ \\
\hline \multicolumn{5}{|l|}{ Culture and preference } \\
\hline Diet preference & $0.021(0.019)$ & $0.026(0.024)$ & $0.004(0.023)$ & $0.028(0.024)$ \\
\hline Activity preference & $-0.001(0.017)$ & $0.017(0.022)$ & $-0.009(0.020)$ & $-0.004(0.021)$ \\
\hline $\begin{array}{l}\text { Other control variables } \\
\text { (e.g. demographic, } \\
\text { community variables) }\end{array}$ & Yes & Yes & Yes & Yes \\
\hline Provincial dummy & Yes & Yes & Yes & Yes \\
\hline Wave dummy & Yes & Yes & Yes & Yes \\
\hline No. of obs. & 2,368 & 2,368 & 2,368 & 2,368 \\
\hline $\begin{array}{l}\mathrm{LM} \text { statistic for the } \\
\text { underidentification test ( } p \text {-value) }\end{array}$ & $10.32(0.006)$ & $10.32(0.006)$ & $10.32(0.006)$ & $10.32(0.006)$ \\
\hline $\begin{array}{l}\text { F-statistic for the weak } \\
\text { identification ( } p \text {-value) }\end{array}$ & $5.19(0.006)$ & $5.19(0.006)$ & $5.19(0.006)$ & $5.19(0.006)$ \\
\hline \multicolumn{5}{|l|}{$\begin{array}{l}\text { Estimation of instruments in the } \\
\text { first stage }\end{array}$} \\
\hline $\begin{array}{l}\text { Proportion of farmland suffering } \\
\text { from natural disasters }\end{array}$ & $-12.764(4.418)^{* * *}$ & $-12.764(4.418)^{* * *}$ & $-12.764(4.418)^{* * *}$ & $\begin{array}{l}-12.764 \\
(4.418)^{* * *}\end{array}$ \\
\hline $\begin{array}{l}\text { Provincial growth rate of average } \\
\text { wage }\end{array}$ & $17.469(6.343)^{* * *}$ & $17.469(6.343)^{* * *}$ & $17.469(6.343)^{* * *}$ & $17.469(6.343)^{* * *}$ \\
\hline $\begin{array}{l}\text { Hansen } \mathbf{J} \text { statistic for the } \\
\text { overidentification test ( } p \text {-value) }\end{array}$ & $0.390(0.532)$ & $0.332(0.565)$ & $0.071(0.790)$ & $1.404(0.236)$ \\
\hline
\end{tabular}


Table 2 Determinants of household nutrient intake (rural)

\begin{tabular}{|c|c|c|c|c|}
\hline \multirow{2}{*}{ Independent variable } & Total calorie & Fat & Carbohydrate & Protein \\
\hline & $(1)$ & (2) & $(3)$ & $(4)$ \\
\hline \multicolumn{5}{|l|}{ Income } \\
\hline $\begin{array}{l}\text { Ln(Household per capita net } \\
\text { income equivalent adult) }\end{array}$ & $-0.051(0.030)^{*}$ & $-0.017(0.049)$ & $-0.028(0.028)$ & $-0.090(0.039)^{* *}$ \\
\hline \multicolumn{5}{|l|}{ Household labour } \\
\hline Out-migration & $0.064(0.025)^{* * *}$ & $0.045(0.038)$ & $0.056(0.023)^{* *}$ & $0.070(0.030)^{* *}$ \\
\hline Local off-farm & $0.066(0.022)^{* * *}$ & $0.047(0.036)$ & $0.051(0.020)^{* *}$ & $0.103(0.028)^{* * * *}$ \\
\hline \multicolumn{5}{|l|}{ Occupation physical activity } \\
\hline Physical activity level & $0.020(0.012)^{*}$ & $-0.010(0.019)$ & $0.023(0.011)^{* *}$ & $0.024(0.015)$ \\
\hline Ethnicity & $-0.117(0.104)$ & $-0.337(0.186)^{*}$ & $-0.007(0.095)$ & $-0.104(0.138)$ \\
\hline Education & $0.045(0.026)^{*}$ & $-0.004(0.042)$ & $0.058(0.023)^{* *}$ & $0.070(0.034)^{* *}$ \\
\hline \multicolumn{5}{|l|}{ Level of food price } \\
\hline Cereals & $-1.384(0.878)$ & $1.792(1.511)$ & $-1.338(0.821)^{*}$ & $-1.815(1.051)^{*}$ \\
\hline Fat and oil & $0.436(0.262)^{*}$ & $0.847(0.458)^{*}$ & $0.445(0.242)^{*}$ & $0.230(0.318)$ \\
\hline Meat & $-0.351(0.858)$ & $-3.866(1.452)^{* * *}$ & $-0.120(0.752)$ & $-0.525(0.963)$ \\
\hline Eggs & $3.072(0.652)^{* * *}$ & $4.122(1.099)^{* * * *}$ & $2.088(0.573)^{* * *}$ & $1.472(0.779)^{*}$ \\
\hline Vegetables & $0.080(0.432)$ & $1.894(0.730)^{* * *}$ & $-0.488(0.360)$ & $-0.854(0.507)^{*}$ \\
\hline \multicolumn{5}{|l|}{ Volatility of food price } \\
\hline Cereals & $2.196(1.187)^{*}$ & $1.509(1.926)$ & $2.597(1.107)^{* *}$ & $2.831(1.491)^{*}$ \\
\hline Fat and oil & $-1.615(0.642)^{* *}$ & $-4.055(1.193)^{* * *}$ & $-1.325(0.588)^{* *}$ & $-1.715(0.768)^{* *}$ \\
\hline Meat & $5.563(1.392)^{* * *}$ & $12.100(2.359)^{* * *}$ & $3.529(1.298)^{* * *}$ & $3.737(1.759)^{* *}$ \\
\hline Eggs & $-1.161(1.742)$ & $2.354(3.013)$ & $-1.023(1.676)$ & $-1.463(2.118)$ \\
\hline Vegetables & $-0.840(0.516)$ & $-3.030(0.881)^{* * *}$ & $-0.402(0.407)$ & $0.471(0.589)$ \\
\hline \multicolumn{5}{|l|}{ Food knowledge } \\
\hline Chinese diet knowledge & $0.016(0.020)$ & $0.069(0.036)^{*}$ & $-0.010(0.019)$ & $0.013(0.025)$ \\
\hline \multicolumn{5}{|l|}{ Culture and preference } \\
\hline Diet preference & $-0.009(0.013)$ & $-0.039(0.022)^{*}$ & $0.004(0.012)$ & $-0.006(0.017)$ \\
\hline Activity preference & $0.006(0.012)$ & $-0.011(0.020)$ & $0.002(0.010)$ & $0.014(0.014)$ \\
\hline $\begin{array}{l}\text { Other control variables } \\
\text { (e.g. demographic, } \\
\text { community variables) }\end{array}$ & Yes & Yes & Yes & Yes \\
\hline Provincial dummy & Yes & Yes & Yes & Yes \\
\hline Wave dummy & Yes & Yes & Yes & Yes \\
\hline No. of obs. & 3,919 & 3,919 & 3,919 & 3,919 \\
\hline $\begin{array}{l}\text { LM statistic for the } \\
\text { underidentification test ( } p \text { - } \\
\text { value) }\end{array}$ & $14.59(0.001)$ & $14.59(0.001)$ & $14.59(0.001)$ & $14.59(0.001)$ \\
\hline $\begin{array}{l}\text { F-statistic for the weak } \\
\text { identification ( } p \text {-value) }\end{array}$ & $7.36(0.001)$ & $7.36(0.001)$ & $7.36(0.001)$ & $7.36(0.001)$ \\
\hline \multicolumn{5}{|l|}{$\begin{array}{l}\text { Estimation of instruments in } \\
\text { the first stage }\end{array}$} \\
\hline $\begin{array}{l}\text { Proportion of farmland } \\
\text { suffering from natural } \\
\text { disasters }\end{array}$ & $-10.722(4.156)^{* * *}$ & $-10.722(4.156)^{* * *}$ & $-10.722(4.156)^{* * *}$ & $-10.722(4.156)^{* * *}$ \\
\hline $\begin{array}{l}\text { Provincial growth rate of } \\
\text { average wage }\end{array}$ & $18.518(4.900)^{* * *}$ & $18.518(4.900)^{* * *}$ & $18.518(4.900)^{* * *}$ & $18.518(4.900)^{* * *}$ \\
\hline $\begin{array}{l}\text { Hansen } \mathrm{J} \text { statistic for the } \\
\text { overidentification test ( } p \text { - } \\
\text { value) }\end{array}$ & $1.391(0.238)$ & $1.395(0.238)$ & $2.308(0.129)$ & $0.294(0.588)$ \\
\hline
\end{tabular}

Note: See Footnote to Table 1. 
Table 3 Distributional impact on household nutrient intake (urban)

\begin{tabular}{|c|c|c|c|c|c|c|c|c|c|}
\hline \multirow[b]{2}{*}{ Independent variable } & \multicolumn{3}{|c|}{ Fat } & \multicolumn{3}{|c|}{ Carbohydrate } & \multicolumn{3}{|c|}{ Protein } \\
\hline & $\begin{array}{c}\tau=0.1 \\
(1)\end{array}$ & $\begin{array}{c}\tau=0.5 \\
(2)\end{array}$ & $\begin{array}{c}\tau=0.9 \\
(3)\end{array}$ & $\begin{array}{c}\tau=0.1 \\
(4)\end{array}$ & $\begin{array}{c}\tau=0.5 \\
(5)\end{array}$ & $\begin{array}{c}\tau=0.9 \\
(6)\end{array}$ & $\begin{array}{c}\tau=0.1 \\
(7)\end{array}$ & $\begin{array}{c}\tau=0.5 \\
(8)\end{array}$ & $\begin{array}{c}\tau=0.9 \\
(9)\end{array}$ \\
\hline $\begin{array}{c}\text { Income } \\
\text { Ln(Household per capita } \\
\text { net income equivalent } \\
\text { adult) }\end{array}$ & $0.044(0.056)$ & $0.047(0.103)$ & $-0.178(0.297)$ & $0.140(0.077)^{*}$ & $0.119(0.080)$ & $0.020(0.169)$ & $0.137(0.035)^{* * *}$ & $0.138(0.083)^{*}$ & $-0.054(0.235)$ \\
\hline \multicolumn{10}{|l|}{$\begin{array}{c}\text { Occupation physical } \\
\text { activity }\end{array}$} \\
\hline Physical activity level & $-0.039(0.038)$ & $-0.037(0.003)^{* * *}$ & $-0.024(0.014)^{*}$ & $0.007(0.048)$ & $0.020(0.002)^{* * *}$ & $0.031(0.010)^{* * *}$ & $-0.015(0.022)$ & $-0.007(0.002)^{* * *}$ & $0.003(0.010)$ \\
\hline Ethnicity & $0.256(0.072)^{* * *}$ & $0.100(0.008)^{* * *}$ & $-0.129(0.036)^{* * *}$ & $0.073(0.044)^{*}$ & $-0.011(0.006)^{*}$ & $-0.133(0.01)^{* * *}$ & $0.107(0.048)^{* *}$ & $0.076(0.007)^{* * *}$ & $-0.067(0.033)^{* *}$ \\
\hline Education & $-0.055(0.096)$ & $-0.039(0.033)$ & $0.032(0.075)$ & $-0.054(0.128)$ & $-0.021(0.026)$ & $0.017(0.043)$ & $-0.023(0.058)$ & $-0.027(0.027)$ & $0.046(0.055)$ \\
\hline \multicolumn{10}{|l|}{ Level of food price } \\
\hline Cereals & $1.252(1.567)$ & $2.175(0.683)^{* * * * *}$ & $1.898(1.420)$ & $-1.887(1.278)$ & $0.798(0.520)$ & $-0.102(1.276)$ & $0.571(1.108)$ & $0.288(0.538)$ & $-0.080(0.876)$ \\
\hline Fat and oil & $0.013(0.587)$ & $0.506(0.134)^{* * * *}$ & $0.453(0.483)$ & $-0.558(0.511)$ & $0.251(0.108)^{* * * *}$ & $0.067(0.355)$ & $-0.308(0.387)$ & $0.084(0.115)$ & $-0.026(0.387)$ \\
\hline Meat & $-4.318(2.620)^{*}$ & $-4.114(0.503)^{* * *}$ & $-4.611(1.593)^{* * *}$ & $-0.728(2.817)$ & $-2.893(0.389)^{* * *}$ & $-1.776(1.221)$ & $-3.679(1.414)^{* * *}$ & $-2.527(0.409)^{* * *}$ & $-2.423(0.935)^{* * * *}$ \\
\hline Eggs & $-1.651(1.373)$ & $-0.904(0.383)^{* *}$ & $-2.001(1.379)$ & $-2.005(1.622)$ & $-2.076(0.293)^{* * *}$ & $-1.066(0.912)$ & $-1.667(0.950)^{*}$ & $-1.418(0.304)^{* * *}$ & $-1.547(1.085)$ \\
\hline Vegetables & $0.832(1.334)$ & $1.393(0.167)^{* * * *}$ & $1.462(0.720)^{* *}$ & $1.896(1.716)$ & $0.893(0.131)^{* * *}$ & $0.542(0.515)$ & $1.016(0.854)$ & $0.455(0.141)^{* * *}$ & $0.400(0.509)$ \\
\hline \multicolumn{10}{|l|}{ Volatility of food price } \\
\hline Cereals & $-3.244(2.412)$ & $-4.607(0.541)^{* * *}$ & $-3.380(2.054)^{*}$ & $0.486(2.704)$ & $-1.190(0.377)^{* * *}$ & $0.693(1.695)$ & $3.707(1.926)^{*}$ & $0.970(0.444)^{* *}$ & $1.845(1.377)$ \\
\hline Fat and oil & $-3.188(1.472)^{* * *}$ & $-3.538(0.386)^{* * * *}$ & $-3.081(0.996)^{* * * *}$ & $0.204(1.173)$ & $0.176(0.295)$ & $-0.347(1.010)$ & $-2.476(0.752)^{* * * *}$ & $-1.967(0.307)^{* * * *}$ & $-2.210(0.664)^{* * * *}$ \\
\hline Meat & $6.027(2.790)^{* * *}$ & $3.072(0.549)^{* * * *}$ & $1.571(2.693)$ & $-0.225(3.105)$ & $1.549(0.441)^{* * * *}$ & $0.581(1.913)$ & $5.874(2.078)^{* * * *}$ & $2.259(0.469)^{* * * *}$ & $0.482(1.960)$ \\
\hline Eggs & $1.917(3.971)$ & $0.746(1.560)$ & $-0.146(2.849)$ & $2.660(3.320)$ & $5.899(1.238)^{* * *}$ & $1.764(2.711)$ & $8.766(2.502)^{* * * *}$ & $4.469(1.280)^{* * *}$ & $1.436(1.990)$ \\
\hline Vegetables & $-0.240(1.131)$ & $-0.792(0.254)^{* * *}$ & $-0.407(0.716)$ & $-2.102(1.390)$ & $-1.665(0.195)^{* * *}$ & $-1.316(0.585)^{* *}$ & $-1.038(0.730)$ & $-0.475(0.207)^{* *}$ & $-0.310(0.560)$ \\
\hline \multicolumn{10}{|l|}{ Food knowledge } \\
\hline Chinese diet knowledge & $-0.001(0.047)$ & $0.029(0.014)^{* *}$ & $0.060(0.029)^{* *}$ & $0.002(0.072)$ & $0.037(0.011)^{* * *}$ & $0.060(0.019)^{* * *}$ & $0.008(0.032)$ & $0.024(0.011)^{* *}$ & $0.043(0.016)^{* * *}$ \\
\hline Culture and preference & & & & & & & & & \\
\hline Diet preference & $0.044(0.029)$ & $0.026(0.004)^{* * *}$ & $0.025(0.019)$ & $0.024(0.020)$ & $0.004(0.003)$ & $0.022(0.015)$ & $0.045(0.018)^{* *}$ & $0.028(0.003)^{* * *}$ & $0.028(0.014)^{* *}$ \\
\hline Activity preference & $0.026(0.026)$ & $0.017(0.004)^{* * *}$ & $0.010(0.019)$ & $-0.034(0.024)$ & $-0.009(0.003)^{* * * *}$ & $0.018(0.012)$ & $-0.010(0.018)$ & $-0.004(0.003)$ & $0.026(0.010)^{* * *}$ \\
\hline $\begin{array}{l}\text { Other control variables } \\
\text { (e.g. demographic, } \\
\text { community variables) }\end{array}$ & Yes & Yes & Yes & Yes & Yes & Yes & Yes & Yes & Yes \\
\hline Provincial dummy & Yes & Yes & Yes & Yes & Yes & Yes & Yes & Yes & Yes \\
\hline Wave dummy & Yes & Yes & Yes & Yes & Yes & Yes & Yes & Yes & Yes \\
\hline No. of obs. & 2,368 & 2,368 & 2,368 & 2,368 & 2,368 & 2,368 & 2,368 & 2,368 & 2,368 \\
\hline $\mathrm{R}^{2}$ & 0.327 & 0.367 & 0.326 & 0.696 & 0.713 & 0.687 & 0.723 & 0.731 & 0.706 \\
\hline $\begin{array}{l}\text { Machado-Santos Silva } \\
\text { test for heteroscedasticity, } \\
\text { Chi-square ( } p \text {-value) }\end{array}$ & $35.30(0.000)$ & $21.24(0.000)$ & $5.51(0.064)$ & $21.43(0.000)$ & $116.15(0.000)$ & $163.72(0.000)$ & $9.09(0.001)$ & $147.12(0.000)$ & $202.27(0.000)$ \\
\hline
\end{tabular}

Note: *****, and $*$ denote $1 \%, 5 \%$, and 10\% significance levels in turn. Heteroscedasticity-robust errors are in parentheses. See Footnote to Table 1. 
Table 4 Distributional impact on household nutrient intake (rural)

\begin{tabular}{|c|c|c|c|c|c|c|c|c|c|}
\hline \multirow[b]{2}{*}{ Independent variable } & \multicolumn{3}{|c|}{ Fat } & \multicolumn{3}{|c|}{ Carbohydrate } & \multicolumn{3}{|c|}{ Protein } \\
\hline & $\begin{array}{c}\tau=0.1 \\
(1)\end{array}$ & $\begin{array}{c}\tau=0.5 \\
(2)\end{array}$ & $\begin{array}{c}\tau=0.9 \\
(3)\end{array}$ & $\begin{array}{c}\tau=0.1 \\
(4)\end{array}$ & $\begin{array}{c}\tau=0.5 \\
(5)\end{array}$ & $\begin{array}{c}\tau=0.9 \\
(6)\end{array}$ & $\begin{array}{c}\tau=0.1 \\
(7)\end{array}$ & $\begin{array}{c}\tau=0.5 \\
(8)\end{array}$ & $\begin{array}{c}\tau=0.9 \\
(9)\end{array}$ \\
\hline $\begin{array}{c}\text { Income } \\
\text { Ln(Household per capita net } \\
\text { income equivalent adult) }\end{array}$ & $-0.001(0.017)$ & $-0.017(0.052)$ & $-0.791(0.278)^{* * * *}$ & $-0.023(0.010)^{* *}$ & $-0.028(0.032)$ & $-0.928(0.200)^{* * *}$ & $-0.064(0.011)^{* * *}$ & $-0.090(0.040)^{* *}$ & $-0.726(0.234)^{* * *}$ \\
\hline $\begin{array}{l}\text { Household labour } \\
\text { Out-migration } \\
\text { Local off-farm }\end{array}$ & $\begin{array}{c}0.100(0.029)^{* * *} \\
0.022(0.029)\end{array}$ & $\begin{array}{l}0.045(0.010)^{* * *} \\
0.047(0.015)^{* * *}\end{array}$ & $\begin{array}{l}-0.005(0.014) \\
0.175(0.047)^{* * *}\end{array}$ & $\begin{array}{l}0.107(0.014)^{* * * *} \\
0.050(0.017)^{* * *}\end{array}$ & $\begin{array}{l}0.056(0.007)^{* * * *} \\
0.051(0.010)^{* * * *}\end{array}$ & $\begin{array}{l}0.033(0.011)^{* * * *} \\
0.202(0.038)^{* * *}\end{array}$ & $\begin{array}{l}0.132(0.016)^{* * *} \\
0.092(0.018)^{* * *}\end{array}$ & $\begin{array}{l}0.070(0.008)^{* * * *} \\
0.103(0.012)^{* * *}\end{array}$ & $\begin{array}{c}0.025(0.015) \\
0.191(0.041)^{* * *}\end{array}$ \\
\hline $\begin{array}{l}\text { Occupation physical activity } \\
\text { Physical activity level }\end{array}$ & $-0.011(0.020)$ & $-0.010(0.002)^{* * *}$ & $-0.038(0.010)^{* * *}$ & $0.029(0.013)^{* *}$ & $0.023(0.001)^{* * * *}$ & $0.006(0.008)$ & $0.036(0.013)^{* * *}$ & $0.024(0.001)^{* * *}$ & $-0.001(0.007)$ \\
\hline $\begin{array}{l}\text { Ethnicity } \\
\text { Education }\end{array}$ & $\begin{array}{c}-0.262(0.081)^{* * *} \\
-0.012(0.027)\end{array}$ & $\begin{array}{r}-0.337(0.007)^{* * *} \\
-0.004(0.015)\end{array}$ & $\begin{array}{r}-0.328(0.078)^{* * *} \\
0.157(0.069)^{* *}\end{array}$ & $\begin{array}{r}0.009(0.043) \\
0.058(0.014)^{* * * *}\end{array}$ & $\begin{array}{l}-0.007(0.004)^{*} \\
0.058(0.009)^{* * *}\end{array}$ & $\begin{array}{l}-0.060(0.025)^{* *} \\
0.249(0.046)^{* * *}\end{array}$ & $\begin{array}{l}-0.113(0.043)^{* * *} \\
0.061(0.014)^{* * *}\end{array}$ & $\begin{array}{l}-0.104(0.006)^{* * *} \\
0.070(0.011)^{* * *}\end{array}$ & $\begin{array}{l}-0.156(0.032)^{* * * *} \\
0.197(0.056)^{* * * *}\end{array}$ \\
\hline $\begin{array}{c}\text { Level of food price } \\
\text { Cereals } \\
\text { Fat and oil } \\
\text { Meat } \\
\text { Eggs } \\
\text { Vegetables }\end{array}$ & $\begin{array}{c}3.951(1.662)^{* *} \\
0.873(0.632) \\
-4.777(1.395)^{* * * *} \\
3.368(1.179)^{* * *} \\
1.566(0.927)^{*}\end{array}$ & $\begin{array}{r}1.792(0.337)^{* * *} \\
0.847(0.116)^{* * *} \\
-3.866(0.278)^{* * * *} \\
4.122(0.169) \\
1.894(0.168)^{* * *}\end{array}$ & $\begin{array}{r}2.368(1.440)^{* * *} \\
0.685(0.689) \\
-5.664(1.245)^{* * * * *} \\
2.771(1.305)^{* * *} \\
2.466(0.774)^{* * *}\end{array}$ & $\begin{array}{r}-0.285(0.970) \\
0.656(0.275)^{* *} \\
-1.172(0.816) \\
1.896(0.694)^{* * *} \\
-0.705(0.351)^{* *}\end{array}$ & $\begin{array}{r}-1.338(0.205)^{* * *} \\
0.445(0.069)^{* * *} \\
-0.120(0.170) \\
2.088(0.101)^{* * * *} \\
-0.488(0.099)^{* * *}\end{array}$ & $\begin{array}{l}-1.226(1.108) \\
-0.152(0.336) \\
-1.341(1.072) \\
-0.533(0.858) \\
1.241(0.444)^{* * *}\end{array}$ & $\begin{array}{r}-1.834(0.979)^{*} \\
0.010(0.296) \\
-0.381(0.800) \\
0.938(0.696) \\
-1.552(0.463)^{* * *}\end{array}$ & $\begin{array}{l}-1.815(0.251)^{* * *} \\
0.230(0.084)^{* * *} \\
-0.525(0.205)^{* * *} \\
1.472(0.120)^{* * *} \\
-0.854(0.109)^{* * *}\end{array}$ & $\begin{array}{c}0.138(0.750) \\
-0.128(0.405) \\
-2.497(0.949)^{* * *} \\
-0.790(0.958) \\
0.430(0.804)\end{array}$ \\
\hline $\begin{array}{c}\text { Volatility of food price } \\
\text { Cereals } \\
\text { Fat and oil } \\
\text { Meat } \\
\text { Eggs } \\
\text { Vegetables }\end{array}$ & $\begin{array}{r}2.885(2.320) \\
-5.508(1.335)^{* * *} \\
11.417(2.318)^{* * * *} \\
2.084(3.049) \\
-3.078(1.312)^{* *}\end{array}$ & $\begin{array}{l}1.509(0.420)^{* * *} \\
-4.055(0.264)^{* * * *} \\
12.100(0.492)^{* * * *} \\
2.354(0.611)^{* * * *} \\
-3.030(0.167)^{* * *}\end{array}$ & $\begin{array}{r}-3.766(2.149)^{*} \\
-2.566\left(1.482{ }^{*}\right. \\
9.478(2.473)^{* * *} \\
0.023(2.811) \\
-2.896(0.827)^{* * * *}\end{array}$ & $\begin{array}{r}3.317(1.128)^{* * * *} \\
-1.406(0.673)^{* * *} \\
5.306(1.469)^{* * *} \\
1.622(2.167) \\
0.073(0.358)\end{array}$ & $\begin{array}{r}2.597(0.264)^{* * * *} \\
-1.325(0.148)^{* * * *} \\
3.529(0.300)^{* * * *} \\
-1.023(0.370)^{* * * *} \\
-0.402(0.116)^{* * * *}\end{array}$ & $\begin{array}{r}-2.948(1.392)^{* *} \\
0.849(0.868) \\
0.179(1.438) \\
0.028(2.264) \\
-1.405(0.411)^{* * *}\end{array}$ & $\begin{array}{r}4.583(1.263)^{* * *} \\
-1.754(0.682)^{* * * *} \\
3.975(1.506)^{* * *} \\
0.577(2.072) \\
1.095(0.529)^{* *}\end{array}$ & $\begin{array}{r}2.830(0.315)^{* * *} \\
-1.715(0.188)^{* * *} \\
3.737(0.366)^{* * *} \\
-1.463(0.451)^{* * *} \\
0.470(0.130)^{* * *}\end{array}$ & $\begin{array}{r}-0.762(1.768) \\
-1.208(0.766) \\
2.080(1.508) \\
1.377(2.161) \\
-0.433(0.908)\end{array}$ \\
\hline $\begin{array}{l}\text { Food knowledge } \\
\text { Chinese diet knowledge } \\
\text { Culture and preference }\end{array}$ & $0.053(0.030)^{* *}$ & $0.069(0.009)^{* * *}$ & $0.159(0.039)^{* * *}$ & $0.005(0.017)$ & $-0.010(0.006)^{*}$ & $0.047(0.020)^{* *}$ & $0.029(0.017)^{*}$ & $0.013(0.007)^{*}$ & $0.057(0.027)^{* *}$ \\
\hline $\begin{array}{l}\text { Diet preference } \\
\text { Activity preference }\end{array}$ & $\begin{array}{c}-0.057(0.017)^{* * *} \\
-0.017(0.015)\end{array}$ & $\begin{array}{l}-0.039(0.003)^{* * *} \\
-0.011(0.005)^{* *}\end{array}$ & $\begin{array}{c}0.048(0.029)^{*} \\
0.027(0.023)\end{array}$ & $\begin{array}{l}0.005(0.011) \\
0.005(0.010)\end{array}$ & $\begin{array}{c}0.004(0.002)^{* * *} \\
0.002(0.003)\end{array}$ & $\begin{array}{l}0.087(0.017)^{* * * *} \\
0.055(0.015)^{* * * *}\end{array}$ & $\begin{array}{r}-0.002(0.011) \\
0.005(0.010)\end{array}$ & $\begin{array}{r}-0.006(0.002)^{* * *} \\
0.014(0.004)^{* * * *}\end{array}$ & $\begin{array}{l}0.051(0.024)^{* * *} \\
0.055(0.018)^{* * * *}\end{array}$ \\
\hline $\begin{array}{l}\text { Other control variables } \\
\text { (e.g. demographic, } \\
\text { community variables) }\end{array}$ & Yes & Yes & Yes & Yes & Yes & Yes & Yes & Yes & Yes \\
\hline $\begin{array}{l}\text { Provincial dummy } \\
\text { Wave dummy }\end{array}$ & $\begin{array}{l}\text { Yes } \\
\text { Yes }\end{array}$ & $\begin{array}{l}\text { Yes } \\
\text { Yes }\end{array}$ & $\begin{array}{l}\text { Yes } \\
\text { Yes }\end{array}$ & $\begin{array}{l}\text { Yes } \\
\text { Yes }\end{array}$ & $\begin{array}{l}\text { Yes } \\
\text { Yes }\end{array}$ & $\begin{array}{l}\text { Yes } \\
\text { Yes }\end{array}$ & $\begin{array}{l}\text { Yes } \\
\text { Yes }\end{array}$ & $\begin{array}{l}\text { Yes } \\
\text { Yes }\end{array}$ & $\begin{array}{l}\text { Yes } \\
\text { Yes }\end{array}$ \\
\hline $\begin{array}{c}\text { No. of obs. } \\
\mathrm{R}^{2} \\
\text { Machado-Santos Silva test for } \\
\text { heteroskedasticity, Chi-square } \\
(p \text {-value })\end{array}$ & $\begin{array}{c}3,919 \\
0.347 \\
36.83(0.000)\end{array}$ & $\begin{array}{c}3,919 \\
0.397 \\
79.07(0.000)\end{array}$ & $\begin{array}{c}3,919 \\
0.344 \\
19.75(0.000)\end{array}$ & $\begin{array}{c}3,919 \\
0.264 \\
9.97(0.007)\end{array}$ & $\begin{array}{c}3,919 \\
0.307 \\
6.53(0.038)\end{array}$ & $\begin{array}{c}3,919 \\
0.272 \\
5.00(0.082)\end{array}$ & $\begin{array}{c}3,919 \\
0.441 \\
58.31(0.000)\end{array}$ & $\begin{array}{c}3,919 \\
0.495 \\
135.03(0.000)\end{array}$ & $\begin{array}{c}3,919 \\
0.474 \\
0.103(0.950)\end{array}$ \\
\hline
\end{tabular}


Table 5 Determinants of the FGT-class nutrition poverty

\begin{tabular}{|c|c|c|c|c|c|c|}
\hline & \multirow{2}{*}{$\begin{array}{c}\text { Urban } \\
\text { FGT(0) } \\
(1)\end{array}$} & \multicolumn{5}{|c|}{ Rural } \\
\hline & & $\begin{array}{c}\text { FGT(1) } \\
(2)\end{array}$ & $\begin{array}{c}\text { FGT(2) } \\
(3)\end{array}$ & $\begin{array}{c}\text { FGT(0) } \\
(4)\end{array}$ & $\begin{array}{c}\text { FGT(1) } \\
(5)\end{array}$ & $\begin{array}{c}\text { FGT(2) } \\
(6)\end{array}$ \\
\hline $\begin{array}{c}\text { Income } \\
\text { Ln(Household per capita net income } \\
\text { equivalent adult) }\end{array}$ & $-0.048(0.040)$ & $-0.019(0.012)$ & $-0.012(0.006)^{*}$ & $0.054(0.032)^{*}$ & $0.005(0.006)$ & $0.00005(0.002)$ \\
\hline $\begin{array}{l}\text { Occupation physical activity } \\
\text { Physical activity level }\end{array}$ & $0.007(0.016)$ & $-0.002(0.004)$ & $-0.001(0.002)$ & $-0.018(0.013)$ & $-0.001(0.003)$ & $0.0003(0.001)$ \\
\hline $\begin{array}{l}\text { Ethnicity } \\
\text { Education }\end{array}$ & $\begin{array}{r}-0.007(0.112) \\
0.011(0.032)\end{array}$ & $\begin{array}{r}-0.002(0.039) \\
0.005(0.008)\end{array}$ & $\begin{array}{r}-0.003(0.024) \\
0.003(0.004)\end{array}$ & $\begin{array}{r}0.188(0.127) \\
-0.033(0.028)\end{array}$ & $\begin{array}{r}0.038(0.025) \\
-0.006(0.006)\end{array}$ & $\begin{array}{r}0.018(0.015) \\
-0.001(0.002)\end{array}$ \\
\hline $\begin{array}{l}\text { Household labour } \\
\text { Out-migration } \\
\text { Local off-farm }\end{array}$ & $\begin{array}{l}- \\
-\end{array}$ & $\begin{array}{l}- \\
-\end{array}$ & $\begin{array}{l}- \\
-\end{array}$ & $\begin{array}{l}-0.049(0.025)^{*} \\
-0.069(0.024)^{* * *}\end{array}$ & $\begin{array}{l}-0.006(0.006) \\
-0.009(0.004)^{* *}\end{array}$ & $\begin{array}{l}-0.002(0.003) \\
-0.001(0.002)\end{array}$ \\
\hline $\begin{array}{c}\text { Level of food price } \\
\text { Cereals } \\
\text { Fat and oil } \\
\text { Meat } \\
\text { Eggs } \\
\text { Vegetables }\end{array}$ & $\begin{array}{c}0.505(1.161) \\
-0.294(0.394) \\
2.384(1.150)^{* *} \\
0.058(0.857) \\
-0.349(0.566)\end{array}$ & $\begin{array}{r}-0.136(0.286) \\
-0.004(0.102) \\
0.528(0.280)^{*} \\
0.169(0.222) \\
-0.208(0.141)\end{array}$ & $\begin{array}{r}-0.148(0.131) \\
-0.026(0.049) \\
0.250(0.129)^{*} \\
0.130(0.109) \\
-0.136(0.070)^{*}\end{array}$ & $\begin{array}{c}-0.119(0.877) \\
-0.937(0.302)^{* * *} \\
1.230(0.816) \\
-2.747(0.684)^{* * *} \\
-0.396(0.426)\end{array}$ & $\begin{array}{c}-0.343(0.178)^{*} \\
-0.224(0.065)^{* * * *} \\
0.550(0.175)^{* * * *} \\
-0.384(0.144)^{* *} \\
-0.140(0.084)^{*}\end{array}$ & $\begin{array}{l}-0.160(0.076)^{* *} \\
-0.070(0.028)^{* *} \\
0.238(0.077)^{* * *} \\
-0.080(0.061) \\
-0.058(0.034)^{*}\end{array}$ \\
\hline $\begin{array}{c}\text { Volatility of food price } \\
\text { Cereals } \\
\text { Fat and oil } \\
\text { Meat } \\
\text { Eggs } \\
\text { Vegetables }\end{array}$ & $\begin{array}{r}1.796(1.809) \\
1.360(1.048) \\
-3.233(1.695)^{*} \\
-3.628(3.155) \\
-0.337(0.691)\end{array}$ & $\begin{array}{r}0.786(0.444)^{*} \\
0.395(0.263) \\
-0.258(0.456) \\
-0.746(0.800) \\
0.137(0.195)\end{array}$ & $\begin{array}{r}0.292(0.209) \\
0.133(0.123) \\
-0.050(0.227) \\
-0.423(0.382) \\
0.140(0.102)\end{array}$ & $\begin{array}{c}-0.767(1.248) \\
1.129(0.725) \\
-6.521(1.551)^{* * * *} \\
0.323(1.841) \\
0.859(0.511)^{*}\end{array}$ & $\begin{array}{c}0.241(0.257) \\
0.421(0.161)^{* * *} \\
-1.142(0.321)^{* * * *} \\
0.038(0.398) \\
0.312(0.104)^{* * *}\end{array}$ & $\begin{array}{c}0.185(0.108)^{*} \\
0.170(0.070)^{* * *} \\
-0.280(0.129)^{* * *} \\
0.043(0.171) \\
0.117(0.043)^{* * *}\end{array}$ \\
\hline $\begin{array}{l}\text { Food knowledge } \\
\text { Chinese diet knowledge } \\
\text { Culture and preference }\end{array}$ & $-0.033(0.026)$ & $-0.011(0.007)^{*}$ & $-0.003(0.003)$ & $-0.025(0.022)$ & $-0.004(0.005)$ & $-0.001(0.001)$ \\
\hline $\begin{array}{c}\text { Other control variables } \\
\text { (e.g. demographic, community } \\
\text { variables) }\end{array}$ & Yes & Yes & Yes & Yes & Yes & Yes \\
\hline Provincial dummy & Yes & Yes & Yes & Yes & Yes & Yes \\
\hline Wave dummy & Yes & Yes & Yes & Yes & Yes & Yes \\
\hline $\begin{array}{c}\text { No. of obs. } \\
\text { LM statistic for the } \\
\text { underidentification test ( } p \text {-value) }\end{array}$ & $\begin{array}{c}2,368 \\
10.32(0.006)\end{array}$ & $\begin{array}{c}2,368 \\
10.32(0.006)\end{array}$ & $\begin{array}{c}2,368 \\
10.32(0.006)\end{array}$ & $\begin{array}{c}3,919 \\
14.59(0.001)\end{array}$ & $\begin{array}{c}3,919 \\
14.59(0.001)\end{array}$ & $\begin{array}{c}3,919 \\
14.59(0.001)\end{array}$ \\
\hline $\begin{array}{l}\text { F-statistic for the weak identification } \\
\text { ( } p \text {-value })\end{array}$ & $5.19(0.006)$ & $5.19(0.006)$ & $5.19(0.006)$ & $7.36(0.001)$ & $7.36(0.001)$ & $7.36(0.001)$ \\
\hline $\begin{array}{l}\text { Sargan Chi-/Hansen J statistic for the } \\
\text { overidentification test ( } p \text {-value) }\end{array}$ & $0.112(0.738)$ & $0.918(0.338)$ & $1.088(0.297)$ & $1.852(0.174)$ & $8.325(0.004)$ & $8.635(0.003)$ \\
\hline
\end{tabular}

Note: ***,**, and * denote $1 \%, 5 \%$, and $10 \%$ significance levels in turn. Heteroscedasticity-robust errors are in parentheses. 
Table 6 Determinants of obesity and undernourishment

\begin{tabular}{|c|c|c|c|c|}
\hline \multirow[b]{2}{*}{ Independent variable } & \multicolumn{2}{|c|}{ Urban } & \multicolumn{2}{|c|}{ Rural } \\
\hline & $\begin{array}{l}\text { Undernourishment } \\
\text { (1) }\end{array}$ & $\begin{array}{l}\text { Obesity } \\
(2)\end{array}$ & $\begin{array}{l}\text { Undernourishment } \\
\text { (3) }\end{array}$ & $\begin{array}{l}\text { Obesity } \\
(4)\end{array}$ \\
\hline \multicolumn{5}{|l|}{ Income } \\
\hline $\begin{array}{l}\text { Ln(Household per capita net } \\
\text { income equivalent adult) }\end{array}$ & $-0.019(0.026)$ & $-0.024(0.020)$ & $0.015(0.019)$ & $0.004(0.015)$ \\
\hline \multicolumn{5}{|l|}{ Occupation physical activity } \\
\hline Physical activity level & $0.0002(0.087)$ & $-0.085(0.064)$ & $-0.127(0.048)^{* * *}$ & $-0.047(0.039)$ \\
\hline Ethnicity & $-1.222(0.768)$ & $-0.003(0.469)$ & $-0.894(0.492)^{*}$ & $0.164(0.356)$ \\
\hline Education & $-0.069(0.130)$ & $-0.215(0.090)^{* *}$ & $-0.227(0.107)^{* *}$ & $-0.141(0.080)^{*}$ \\
\hline \multicolumn{5}{|l|}{ Level of food price } \\
\hline Cereals & $16.148(9.434)^{*}$ & $-12.769(6.207)^{* *}$ & $2.277(6.325)$ & $0.574(5.003)$ \\
\hline Fat and oil & $1.933(3.346)$ & $-5.427(2.142)^{* *}$ & $1.811(2.150)$ & $-1.719(1.554)$ \\
\hline Meat & $-4.760(9.284)$ & $5.646(5.887)$ & $-4.172(6.326)$ & $-1.594(4.687)$ \\
\hline Eggs & $-1.897(5.965)$ & $-1.127(4.072)$ & $4.027(3.978)$ & $-5.500(3.018)^{*}$ \\
\hline Vegetables & $-5.615(4.876)$ & $-0.524(2.873)$ & $-3.734(3.493)$ & $1.532(2.388)$ \\
\hline \multicolumn{5}{|l|}{ Volatility of food price } \\
\hline Cereals & $-5.454(17.104)$ & $15.421(10.268)$ & $19.799(9.424)^{* *}$ & $-7.027(7.171)$ \\
\hline Fat and oil & $6.870(7.555)$ & $-1.210(5.111)$ & $-2.396(4.594)$ & $2.762(3.941)$ \\
\hline Meat & $11.469(14.678)$ & $-11.736(10.526)$ & $24.832(10.622)^{* *}$ & $-0.359(8.265)$ \\
\hline Eggs & $26.020(22.864)$ & $8.006(14.237)$ & $24.806(15.610)$ & $-6.633(10.707)$ \\
\hline Vegetables & $3.136(5.375)$ & $0.445(3.347)$ & $2.970(3.795)$ & $0.591(2.747)$ \\
\hline \multicolumn{5}{|l|}{ Food knowledge } \\
\hline Chinese diet knowledge & $-0.104(0.177)$ & $0.192(0.118)$ & $0.037(0.135)$ & $0.015(0.101)$ \\
\hline \multicolumn{5}{|l|}{ Culture and preference } \\
\hline Diet preference & $0.076(0.136)$ & $-0.148(0.097)$ & $0.213(0.082)^{* * *}$ & $-0.013(0.066)$ \\
\hline Activity preference & $0.276(0.118)^{* *}$ & $-0.039(0.082)$ & $-0.127(0.073)^{*}$ & $-0.004(0.057)$ \\
\hline $\begin{array}{l}\text { Other control variables } \\
\text { (e.g. demographic, community } \\
\text { variables) }\end{array}$ & Yes & Yes & Yes & Yes \\
\hline Provincial dummy & Yes & Yes & Yes & Yes \\
\hline Wave dummy & Yes & Yes & Yes & Yes \\
\hline No. of obs. & 1,985 & 1,985 & 3,224 & 3,224 \\
\hline Log-likelihood & -527.531 & $-1,094.825$ & $-1,114.585$ & $-1,798.451$ \\
\hline Wald $\chi^{2}$ ( $p$-value) & $49.71(0.291)$ & $78.98(0.001)$ & $141.46(0.000)$ & $146.76(0.000)$ \\
\hline
\end{tabular}




\section{Appendix 1. Definition and descriptive statistics of variables}

\section{Variable \\ Modified OECD equivalent}

household size

Household equivalent per capita net ncome

Household equivalent per capita agricultural income

Household equivalent per capita business income

Household equivalent per capita wage income

Household equivalent per capita total calorie intake

Household equivalent per capita direct calorie intake

Household equivalent per capita calorie intake from $\mathrm{fat}$

Household equivalent per capita calorie intake from carbohydrate

Household equivalent per capita calorie intake from protein

Age

Gender

Ethnicity

Education

Water source

Toilet type

Cooking fuel

Definition

Weighted sum of household members. The first adult in the household has a weight of 1. Each additional adult aged 14 and over has a weight of 0.5. Each child aged under 14 has a weight of 0.3. This definition can be found at Eurostat: http://epp.eurostat.ec.europa.eu/statistics_explained/index.php/Glossary:Equivalised_disposable_income [accessed December 5, 2013]

Household net income divided by the equivalent household size. Household net income is total income (including agricultural and family business income, wages, transfer income and asset income) minus related costs, taxes and fees. All monetary values are transformed into real terms by dividing them by the spatial CPI calculated by the CHNS team.

Household net agricultural income divided by the equivalent household size. Household net agricultural income is the total agricultura income produced by the household net of relevant costs. All monetary values are transformed into real terms by dividing them by the spatia CPI calculated by the CHNS team.

Household net business income divided by the equivalent household size. Household net business income is total income from househol small business activities net of relevant costs. All monetary values are transformed into real terms by dividing them by the spatial CPI calculated by the CHNS team.

Household wage income divided by the equivalent household size. Household wage income is the sum of individual household members wages. All monetary values are transformed into real terms by dividing them by the spatial CPI calculated by the CHNS team.

The sum of individual total calories intake within the household, which is calculated by the CHNS team, divided by the equivalent household size. The CHNS team calculated the individual total calories intake as the sum of direct calories intake and the converted amount from carbohydrate, fat and protein. Their conversion rates are from FAO (2003): 1 gram of fat, carbohydrate and protein equals separately 9, 4 and $4 \mathrm{kcal}$.

The sum of individual direct calories intake within the household divided by the equivalent household size.

The sum of individual calories intake inverted from fat within the household divided by the equivalent household size. According to FAO (2003), 1 gram of fat=9 kcal

The sum of individual calories intake inverted from carbohydrate within the household divided by the equivalent household size. According 29,402 to $\mathrm{FAO}(2003), 1$ gram of carbohydrate $=4 \mathrm{kcal}$.

The sum of individual calories intake inverted from protein within the household divided by the equivalent household size. According to FAO (2003), 1 gram of protein $=4 \mathrm{kcal}$.

Average age of household members in years. We also constructed 5 dummies indicating to which age cohort the household belongs according to its average age. The 5 age cohorts are defined in a 10 -year interval: the average age lies (1) below 30; (2) in [30, 40); (3) in [40, $50) ;(4)$ in $[50,60)$; and (5) above 60 years.

Gender of household head, $0=$ female, $1=$ male.

Averaged education level among all household members. For each member, the educational level is a categorical variable, i.e., having completed or finished part of the following educational levels. Categorical variable, $0=$ illiterate, $1=$ primary education, $2=$ junior high school, $3=$ senior high school, $4=$ higher education.

Categorical variable, $1=$ natural water (rainfall, ice, snow, creek, spring, lake, and river), $2=$ open well $(\mathrm{depth} \leq 5 \mathrm{~m}), 3=$ ground water (depth>5m), 4=tap water or water plant.

Categorical variable, $0=$ no toilet, $1=$ cement or earth openpit, $2=$ no flush, $3=$ flush but outside house, public restroom, $4=$ in-house flush.

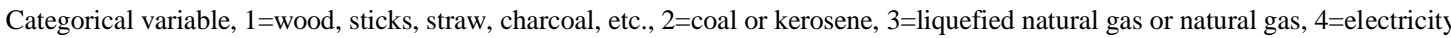


Average physical activity for hh members with working ability (age $>7$ as defined by the CHNS team). Each hh member's physical activity is a 1-5 categorical indicator also defined by the CHNS team: 1 means very light physical activity (working in a sitting position, e.g., office

Illness etc.); 3 means moderate physical activity (student, driver, electrician, metal worker, etc.); 4 means heavy physical activity (farmer, dancer, steel worker, athlete, etc.); and 5 means very heavy physical activity (loader, logger, miner, stonecutter, etc.).

\section{Insurance}

Level of food price

Level of cereal price

Level of fat price

Level of meat price

Level of egg price

Volatility of various food prices

Chinese diet knowledge

Diet preference

Activity preference

\section{Population density}

Transport

Health services

Dummy variable, $1=$ any household member was ill in the last 4 weeks, $0=$ otherwise.

Dummy variable, $1=$ any household member has health insurance, $0=$ otherwise.

Provincial index of real food price, 2009 prices $=1$.

Provincial index of real cereal price, 2009 prices $=1$.

Provincial index of real fat $\&$ oil prices, 2009 prices $=1$.

Provincial index of real meat price, 2009 prices $=1$

Provincial index of real egg price, 2009 prices $=1$.

Coefficient of variation of the level of each food price defined above in a two-year window.

Dummy variable, $1=$ any household member knows the Chinese diet guidelines (also known as the Chinese diet pagoda), $0=$ otherwise

Average categorical variable. For each household member, 1='dislike very much'; 2='dislike', 3='neutral', 4='like', and 5='like very much' for (1) fast food, (2) salty snack foods, and (3) soft drinks or sugared drinks. We first calculate each household member's average preference across 3 sorts of high-energy foods and then, calculate the average preference within the household.

Average categorical variable. For each household member, 1='dislike very much', 2='dislike', 3='neutral', 4='like', and 5='like very much' for participation in (1) walking, (2) Tai Chi, and (3) sports or body building. We first calculate each household member's average preference across 3 sorts of high-energy foods and then, calculate the average preference within the household.

Total population of the community divided by community area, from local official records. categorized as (1) within community, (2) $\leq 1 \mathrm{~km}$ from community, and (3) $\geq 1 \mathrm{~km}$ from community.

Community index reflecting the number and type of health facilities in or nearby $(\leq 12 \mathrm{~km})$ the community and number of pharmacies in

4.431

2.456

5.941 bakeries, ice cream parlours, fast food restaurants, fruit and vegetable stands, bars within the community boundaries.

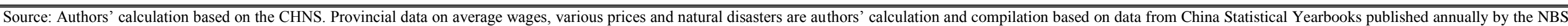

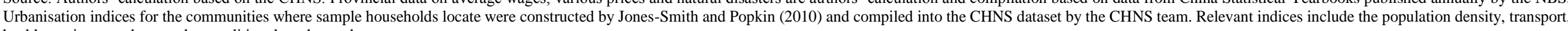
health services, modern market, traditional market and economy.

Note: a. Data have been collected since 1993. b. Data have been collected since 1997. c. Data have been collected since 2004 


\section{Appendix 2. Determinants of household nutrition -OLS estimates}

\section{Urban households}

\begin{tabular}{|c|c|c|c|c|}
\hline \multirow{2}{*}{ Independent variable } & Total calorie & Fat & Carbohydrate & Protein \\
\hline & $(1)$ & $(2)$ & $(3)$ & $(4)$ \\
\hline \multicolumn{5}{|l|}{ Income } \\
\hline $\begin{array}{l}\text { Ln(Household per capita net } \\
\text { income equivalent adult) }\end{array}$ & $0.001(0.004)$ & $0.001(0.006)$ & $-0.0002(0.004)$ & $0.006(0.004)$ \\
\hline Ethnicity & $-0.136(0.071)^{*}$ & $0.013(0.137)$ & $-0.242(0.078)^{* * *}$ & $-0.178(0.105)^{*}$ \\
\hline Education & $0.002(0.020)$ & $-0.024(0.031)$ & $0.018(0.022)$ & $0.016(0.023)$ \\
\hline \multicolumn{5}{|l|}{ Occupation physical activity } \\
\hline Physical activity level & $0.0001(0.011)$ & $-0.035(0.017)^{* *}$ & $0.026(0.013)^{* *}$ & $0.0002(0.014)$ \\
\hline \multicolumn{5}{|l|}{ Level of food price } \\
\hline Cereals & $0.283(0.839)$ & $1.827(1.334)$ & $-0.116(0.937)$ & $-0.721(0.934)$ \\
\hline Fat and oil & $-0.013(0.299)$ & $0.432(0.501)$ & $0.056(0.313)$ & $-0.133(0.329)$ \\
\hline Meat & $-2.756(0.857)^{* * * *}$ & $-3.820(1.303)^{* * * *}$ & $-2.121(0.958)^{* *}$ & $-1.675(0.892)^{*}$ \\
\hline Eggs & $-0.522(0.563)$ & $-0.406(0.897)$ & $-0.768(0.627)$ & $0.025(0.611)$ \\
\hline Vegetables & $0.601(0.393)$ & $1.185(0.595)^{* *}$ & $0.347(0.441)$ & $-0.148(0.437)$ \\
\hline \multicolumn{5}{|l|}{ Volatility of food price } \\
\hline Cereals & $-1.871(1.265)$ & $-4.591(2.185)^{* *}$ & $-1.148(1.315)$ & $1.017(1.482)$ \\
\hline Fat and oil & $-1.644(0.753)^{* *}$ & $3.968(1.245)^{* * *}$ & $-0.951(0.813)$ & $-3.212(0.806)^{* * *}$ \\
\hline Meat & $2.066(1.395)$ & $2.970(2.197)$ & $1.283(1.424)$ & $1.964(1.509)$ \\
\hline Eggs & $0.637(2.167)$ & $-1.191(3.265)$ & $0.818(2.185)$ & $-1.140(2.244)$ \\
\hline Vegetables & $-0.384(0.470)$ & $-0.399(0.751)$ & $-0.634(0.514)$ & $0.663(0.510)$ \\
\hline \multicolumn{5}{|l|}{ Food knowledge } \\
\hline Chinese diet knowledge & $0.041(0.020)^{* *}$ & $0.037(0.029)$ & $0.058(0.022)^{* * *}$ & $0.047(0.023)^{* *}$ \\
\hline \multicolumn{5}{|l|}{ Culture and preference } \\
\hline Diet preference & $0.030(0.015)^{* *}$ & $0.030(0.023)$ & $0.015(0.017)$ & $0.040(0.018)^{* *}$ \\
\hline Activity preference & $0.013(0.013)$ & $0.023(0.021)$ & $0.008(0.014)$ & $0.015(0.014)$ \\
\hline \multicolumn{5}{|l|}{$\begin{array}{l}\text { (e.g. demographic, } \\
\text { community variables) }\end{array}$} \\
\hline Provincial dummy & Yes & Yes & Yes & Yes \\
\hline Wave dummy & Yes & Yes & Yes & Yes \\
\hline No. of obs. & 2,368 & 2,368 & 2,368 & 2,368 \\
\hline $\mathrm{R}^{2}$ & 0.058 & 0.002 & 0.100 & 0.093 \\
\hline$F$-test $(p$-value $)$ & $3.90(0.000)$ & $2.12(0.000)$ & $5.79(0.000)$ & $4.03(0.000)$ \\
\hline \multicolumn{5}{|c|}{ Rural households } \\
\hline \multirow{2}{*}{ Independent variable } & Total calorie & Fat & Carbohydrate & Protein \\
\hline & $(1)$ & $(2)$ & (3) & $(4)$ \\
\hline \multicolumn{5}{|l|}{ Income } \\
\hline $\begin{array}{l}\mathrm{Ln}(\text { Household per capita net } \\
\text { income equivalent adult) }\end{array}$ & $0.007(0.002)^{* * *}$ & $0.014(0.005)^{* * *}$ & $0.014(0.005)^{* * *}$ & $0.007(0.002)^{* * *}$ \\
\hline \multicolumn{5}{|l|}{ Occupation physical activity } \\
\hline Physical activity level & $0.003(0.008)$ & $-0.019(0.014)$ & $-0.019(0.014)$ & $-0.002(0.008)$ \\
\hline \multicolumn{5}{|l|}{ Health } \\
\hline Illness & $0.001(0.013)$ & $0.011(0.026)$ & $0.011(0.026)$ & $0.014(0.014)$ \\
\hline Insurance & $0.018(0.018)$ & $0.040(0.035)$ & $0.040(0.035)$ & $0.045(0.018)^{* *}$ \\
\hline \multicolumn{5}{|l|}{ Level of food price } \\
\hline Cereals & $-0.463(0.704)$ & $2.318(1.346)^{*}$ & $2.318(1.346)^{*}$ & $-0.272(0.750)$ \\
\hline Fat and oil & $0.370(0.221)^{*}$ & $0.801(0.431)^{*}$ & $0.801(0.431)^{*}$ & $0.130(0.237)$ \\
\hline Meat & $-0.686(0.743)$ & $-3.984(1.357)^{* * * *}$ & $-3.984(1.357)^{* * *}$ & $-1.168(0.723)$ \\
\hline Eggs & $2.322(0.475)^{* * *}$ & $3.724(0.911)^{* * *}$ & $3.724(0.911)^{* * *}$ & $0.201(0.467)$ \\
\hline Vegetables & $0.364(0.319)$ & $2.057(0.627)^{* * *}$ & $2.057(0.627)^{* * *}$ & $-0.401(0.350)$ \\
\hline \multicolumn{5}{|l|}{ Volatility of food price } \\
\hline Cereals & $1.130(1.032)$ & $0.782(1.839)$ & $0.782(1.839)$ & $1.286(1.148)$ \\
\hline Fat and oil & $-2.018(0.530)^{* * *}$ & $-4.283(1.083)^{* * *}$ & $-4.283(1.083)^{* * * *}$ & $\begin{array}{l}-2.394 \\
(0.571)^{* * *}\end{array}$ \\
\hline Meat & $4.171(1.085)^{* * *}$ & $11.215(2.108)^{* * *}$ & $11.215(2.108)^{* * *}$ & $1.607(1.180)$ \\
\hline Eggs & $-0.574(1.475)$ & $2.596(2.793)$ & $2.596(2.793)$ & $-0.294(1.628)$ \\
\hline Vegetables & $-1.178(0.390)^{* * *}$ & $-3.228(0.775)^{* * *}$ & $-3.228(0.775)^{* * *}$ & $-0.083(0.394)$ \\
\hline \multicolumn{5}{|l|}{ Food knowledge } \\
\hline Chinese diet knowledge & $0.014(0.017)$ & $0.070(0.033)^{* *}$ & $0.070(0.033)^{* *}$ & $0.009(0.019)$ \\
\hline
\end{tabular}




\begin{tabular}{|c|c|c|c|c|}
\hline Diet preference & $-0.003(0.011)$ & $-0.035(0.020)^{*}$ & $-0.035(0.020)^{*}$ & $0.003(0.012)$ \\
\hline Activity preference & $0.001(0.010)$ & $-0.014(0.018)$ & $-0.014(0.018)$ & $0.004(0.010)$ \\
\hline Provincial dummy & Yes & Yes & Yes & Yes \\
\hline Wave dummy & Yes & Yes & Yes & Yes \\
\hline No. of obs. & 3,919 & 3,919 & 3,919 & 3,919 \\
\hline $\mathrm{R}^{2}$ & 0.049 & 0.004 & 0.004 & 0.149 \\
\hline$F$-test ( $p$-value) & $5.10(0.000)$ & $5.64(0.000)$ & $5.64(0.000)$ & $3.57(0.000)$ \\
\hline
\end{tabular}

Note: $* * *, * *$, and $*$ denote $1 \%, 5 \%$, and $10 \%$ significance levels in turn. Heteroscedasticity-robust errors are in parentheses.

\section{Appendix 3. Determinants of household nutrition (Fixed Effects IV estimation-Full} sample with fewer explanatory variables)

\begin{tabular}{|c|c|c|c|c|c|c|c|c|}
\hline \multirow[b]{2}{*}{ Independent variable } & \multicolumn{4}{|c|}{ Urban } & \multicolumn{4}{|c|}{ Rural } \\
\hline & $\begin{array}{l}\text { Total } \\
\text { (1) }\end{array}$ & $\begin{array}{l}\text { Fat } \\
\text { (2) }\end{array}$ & $\begin{array}{c}\text { Carbohydrate } \\
\text { (3) }\end{array}$ & $\begin{array}{l}\text { Protein } \\
\text { (4) }\end{array}$ & $\begin{array}{c}\text { Total } \\
(5)\end{array}$ & $\begin{array}{l}\text { Fat } \\
(6)\end{array}$ & $\begin{array}{c}\text { Carbohydrate } \\
\text { (7) }\end{array}$ & $\begin{array}{l}\text { Protein } \\
(8)\end{array}$ \\
\hline \multicolumn{9}{|l|}{ Income } \\
\hline $\begin{array}{l}\text { Ln(Household per capita net } \\
\text { income equivalent adult) }\end{array}$ & $\begin{array}{l}0.114 \\
(0.053)^{* *}\end{array}$ & $\begin{array}{l}0.160 \\
(0.084)^{*}\end{array}$ & $\begin{array}{c}0.054 \\
(0.046)\end{array}$ & $\begin{array}{l}0.110 \\
(0.056)^{*}\end{array}$ & $\begin{array}{l}0.084 \\
(0.032)^{* * *}\end{array}$ & $\begin{array}{l}-0.081 \\
(0.057)\end{array}$ & $\begin{array}{l}0.164 \\
(0.045)^{* * *}\end{array}$ & $\begin{array}{l}0.112 \\
(0.039)^{* * *}\end{array}$ \\
\hline Ethnicity & $\begin{array}{l}-0.007 \\
(0.038)\end{array}$ & $\begin{array}{l}-0.035 \\
(0.064)\end{array}$ & $\begin{array}{l}-0.018 \\
(0.036)\end{array}$ & $\begin{array}{l}0.00005 \\
(0.042)\end{array}$ & $\begin{array}{l}0.049 \\
(0.018)^{* *}\end{array}$ & $\begin{array}{l}0.088 \\
(0.036)^{\text {*** }}\end{array}$ & $\begin{array}{c}0.033 \\
(0.025)\end{array}$ & $\begin{array}{c}0.023 \\
(0.022)\end{array}$ \\
\hline $\begin{array}{l}\text { Demographic variables } \\
\text { Fixed effects }\end{array}$ & Yes & Yes & Yes & Yes & Yes & Yes & Yes & Yes \\
\hline Household fixed effects & Yes & Yes & Yes & Yes & Yes & Yes & Yes & Yes \\
\hline Provincial dummy & Yes & Yes & Yes & Yes & Yes & Yes & Yes & Yes \\
\hline Wave dummy & Yes & Yes & Yes & Yes & Yes & Yes & Yes & Yes \\
\hline No. of obs. & 7,831 & 7,831 & 7,831 & 7,831 & 18,416 & 18,416 & 18,416 & 18,416 \\
\hline LM statistic for the & 9.576 & 9.576 & 9.576 & 9.576 & 22.522 & 22.522 & 22.522 & 22.522 \\
\hline underidentification test ( $p$-value) & $(0.008)$ & $(0.008)$ & $(0.008)$ & $(0.008)$ & $(0.000)$ & $(0.000)$ & $(0.000)$ & $(0.000)$ \\
\hline F-statistic for the weak & 4.850 & 4.850 & 4.850 & 4.850 & 11.270 & 11.270 & 11.270 & 11.270 \\
\hline identification ( $p$-value) & $(0.008)$ & $(0.008)$ & $(0.008)$ & $(0.008)$ & $(0.000)$ & $(0.000)$ & $(0.000)$ & $(0.000)$ \\
\hline \multicolumn{9}{|l|}{$\begin{array}{l}\text { Estimation of instruments in the } \\
\text { first stage }\end{array}$} \\
\hline Proportion of farmland suffering & -1.120 & -1.120 & -1.120 & -1.120 & -1.247 & -1.247 & -1.247 & -1.247 \\
\hline from natural disasters & $(0.445)^{* *}$ & $(0.445)^{* *}$ & $(0.445)^{* *}$ & $(0.445)^{* *}$ & $(0.263)^{* * *}$ & $(0.263)^{* * * *}$ & $(0.263)^{* * *}$ & $(0.263)^{* * * *}$ \\
\hline Provincial growth rate of & 2.668 & 2.668 & 2.668 & 2.668 & 0.352 & 0.352 & 0.352 & 0.352 \\
\hline $\begin{array}{l}\text { average wage } \\
\text { Hansen } \mathbf{J} \text { statistic for the }\end{array}$ & $\begin{array}{c}(1.529) \\
0.004\end{array}$ & $\begin{array}{c}(1.529) \\
0.754\end{array}$ & $\begin{array}{c}(1.529) \\
0.155\end{array}$ & $\begin{array}{c}(1.529) \\
0.187\end{array}$ & $\begin{array}{c}(1.082) \\
1.490\end{array}$ & $\begin{array}{c}(1.082) \\
0.002\end{array}$ & $\begin{array}{c}(1.082) \\
0.156\end{array}$ & $\begin{array}{c}(1.082) \\
1.278\end{array}$ \\
\hline overidentification test ( $p$-value) & $(0.947)$ & $(0.355)$ & $(0.282)$ & $(0.665)$ & $(0.222)$ & $(0.967)$ & $(0.693)$ & $(0.258)$ \\
\hline
\end{tabular}


Appendix 4. Trends of increasing weight and decreasing intensity of physical activity (by age cohort)

a. Average weight

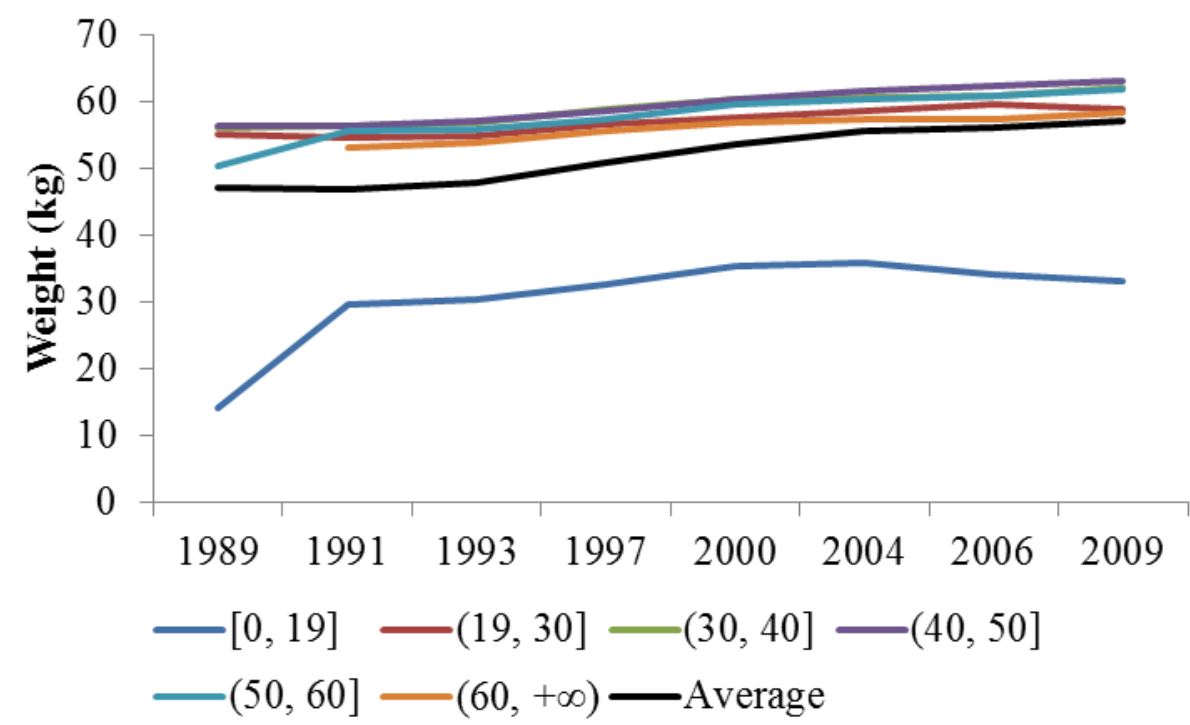

b. Average level of physical activity

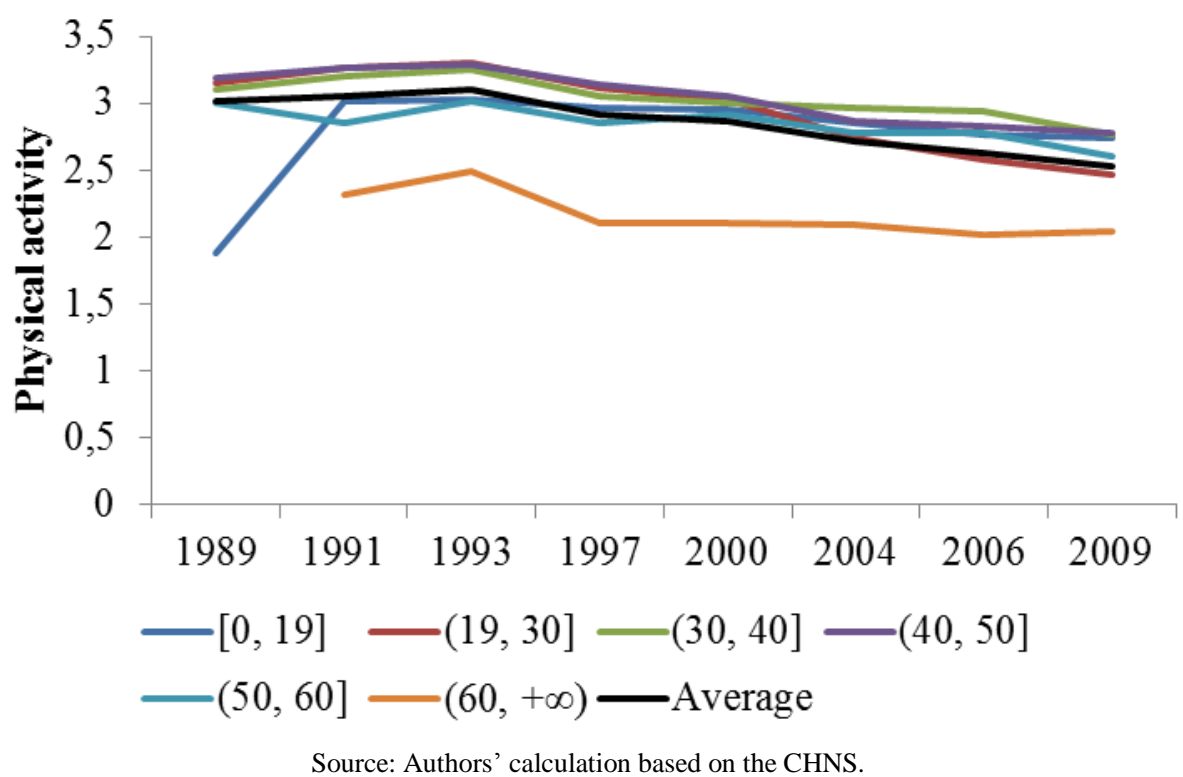

